\title{
A decade of energy and mass balance investigations on the glacier Kongsvegen, Svalbard
}

\author{
F. Karner, ${ }^{1}$ F. Obleitner, ${ }^{1}$ T. Krismer, ${ }^{2}$ J. Kohler, ${ }^{3}$ and W. Greuell ${ }^{4}$ \\ Received 21 June 2012; revised 19 October 2012; accepted 4 December 2012; published 21 May 2013.
}

[1] Kongsvegen is an Arctic glacier located in northwest Spitzbergen. We use meteorological observations made near the average equilibrium line of Kongsvegen during the decade 2001 to 2010 to drive a glacier energy and mass balance model. Average daily and seasonal cycles are analyzed over the course of a full decade, as well as the interannual variations of the meteorological parameters and of the mass and energy balance components. The calculated average of net radiation is close to zero and the sensible heat flux is the most important and continuous source of energy at the surface. The latent heat flux is a weak source of energy as well. The resultant flux constellation yields a surplus of energy accumulating throughout the decade $\left(9.5 \mathrm{~W} \mathrm{~m}^{-2}\right)$ and fosters a negative specific surface mass balance throughout the investigated decade $(-1.8 \mathrm{~m}$ w. eq.). The most significant mass loss occurred during the middle of the decade (2004 until 2006), with positive surface mass balances observed afterward when significant amounts of superimposed ice were formed. This development is well correlated to the total surface mass balance of the glacier. Application of monthly temperature and precipitation perturbations corroborates earlier studies indicating a high sensitivity of the mass balance to energy fluxes depending on temperature conditions during summer.

Citation: Karner, F., F. Obleitner, T. Krismer, J. Kohler, and W. Greuell (2013), A decade of energy and mass balance investigations on the glacier Kongsvegen, Svalbard, J. Geophys. Res. Atmos., 118, 3986-4000, doi:10.1029/2012JD018342.

\section{Introduction}

[2] Arctic environments are particularly sensitive to climate change [Lemke et al., 2007; Christensen et al., 2007], with average Arctic temperatures increasing at almost twice the global average rate in the past 100 years. The Svalbard archipelago has experienced a warming since the 1960s [Førland et al., 2011; Johannessen et al., 2004; Overland et al., 2004], most significantly for spring with annual precipitation increasing as well. There is also high regional and decadal variability, related to long-term changes in atmospheric circulation patterns in the Norwegian Arctic [Hanssen-Bauer and Førland, 1998].

[3] Svalbard is one of the most glaciated regions in the Arctic. Because Svalbard glaciers exist in a relatively warm regime, they are expected to react early to climatic change [Oerlemans et al., 2005]. Interestingly however, some Svalbard glaciers remained fairly close to balance or even gained mass during the 1990s [Bamber et al., 2004]. Nevertheless, a net mass loss was calculated considering all glaciers and ice

\footnotetext{
${ }^{1}$ Institute of Meteorology and Geophysics, Innsbruck University, Austria.

${ }^{2}$ Max Planck Institute for Meteorology, Hamburg, Germany.

${ }^{3}$ Norwegian Polar Institute, Tromsø, Norway.

${ }^{4}$ KNMI, de Bilt, Netherlands.

Corresponding author: F. Karner, Institute of Meteorology and Geophysics, Innsbruck University, Austria. (florian.karner@gmail.com)

(C)2012. American Geophysical Union. All Rights Reserved. 2169-897X/13/2012JD018342
}

caps on the archipelago [Hagen et al., 2003b] The most recent estimates find that over the past 40 years Svalbard glaciers have lost $5-10 \mathrm{~km}^{3} \mathrm{yr}^{-1}$ of ice and many of them experienced a significant retreat and thinning of their tongues, especially in the south of the archipelago [Moholdt et al., 2010; Nuth et al., 2010]. Oerlemans et al. [2005] projected these trends into the future but major uncertainties remain concerning, e.g., the dynamics of calving and surging glaciers. Hodgkins [1997] suggested that regional climate change has probably influenced the thermal regimes of some Svalbard glaciers, which in turn affects their dynamic response.

[4] Kongsvegen glacier is one of 13 glaciers in Svalbard with a long-term mass balance record [Hagen and Listøl, 1990; Lefauconnier et al., 1999; WGMS, 2009]. Annual data are available since 1987, and reveal a generally negative net balance of the glacier. Kongsvegen shows less mass losses $(-1.8 \mathrm{~m}$ w. eq.) during the period 1965 to 2005 compared to neighboring glaciers like Midre Lovénbreen $(-14.7 \mathrm{~m}$ w. eq.) and Austre Bøggerbreen ( $-18.8 \mathrm{~m}$ w. eq.) [WGMS, 2009]. This may be related to a mass gain during the early $1990 \mathrm{~s}$, but the last decade was characterized by mostly negative mass balances. Hagen et al. [2003a] interpreted the temporary mass gain as a dynamical response to the last surge, which occurred in 1948. Interannual variability of the formation of superimposed ice was recognized playing an important role for the mass balance of the glacier in general [König et al., 2002; Obleitner and Lehning, 2004; Brandt et al., 2008]. 
[5] The surface energy balance provides the link between atmospheric forcings and the evolution of snow and ice on a glacier. The associated energy fluxes affect ablation of snow and ice. In turn, the presence and the structural changes of snow upon glacier ice affect the physical properties of the surface and the adjacent atmospheric boundary layer. Radiation and turbulent fluxes normally play the dominant role, which on polar glaciers are strongly conditioned by the lack (abundance) of solar radiation during polar night (day).

[6] In the Kongsfjord environment, the energy balance was recently investigated for permafrost surfaces [Argentini et al., 2003; Westermann et al., 2009] and on sea ice [Nicolaus et al., 2003; Mäkiranta et al., 2011], but there are few investigations on glacier surfaces in this area. At Kongsvegen itself, Obleitner and Lehning [2004] investigated the formation of superimposed ice and Greuell et al. [2007] examined the influence of albedo on the mass balance of the glacier. Erath [2005], Krismer [2009], and Papadopoulos [2010] performed model studies and observed the atmospheric boundary layer during summer time, respectively. Energy balance studies were also performed on Midre Lovénbreen glacier which is located $\sim 5$ $\mathrm{km}$ to the west of Kongsvegen glacier [Arnold et al., 2006; Wright et al., 2005].

[7] Meanwhile, an energy balance station (EBS) was operational on Kongsvegen since 2000 and was visited during spring and autumn measurements of the glacier's mass balance. Based on these data we analyze the decadal features of the meteorological conditions and of the energy balance at this site and their relationship to the glacier's mass balance. These evaluations also use a mass and energy balance model, allowing us to investigate the impact of uncertainties in measurements and parameterizations, as well as to examine the sensitivity of the glacier mass balance to potential climate changes.

\section{The Investigation Site}

[8] Kongsvegen is located at the northwestern coast of Svalbard (Figure 1). The glacier flows to the northwest, has an area of $\sim 100 \mathrm{~km}^{2}$ and a length of $26 \mathrm{~km}$, with slopes ranging from 0.5 to $2.5^{\circ}$. It originates at a saddle connecting to the southeast flowing Sveabreen ( $750 \mathrm{~m}$ above sea level (asl)) and its tongue just approaches the sea, without calving into it. Ice velocities are less than $5 \mathrm{~m} \mathrm{a}^{-1}$ [Melvold and Hagen, 1998], consistent with the fact that Kongsvegen is currently in a quiescent phase of its surge cycle. Radio-echo soundings reveal a maximum ice thickness of about $440 \mathrm{~m}$ [Björnsson et al., 1996]. Radar and borehole temperature measurements indicate that the glacier is polythermal meaning that the ice is cold in the upper layers of the ablation area, but that the glacier is mostly temperate in the higher basins [Björnsson et al., 1996]. Melt water retention and refreezing have a large effect on the mass balance and on the thermal regime of the glacier [König et al., 2002; Hagen et al., 2003a; Obleitner and Lehning, 2004; Brandt et al., 2008].

[9] The present work considers meteorological and glaciological data collected close to the average equilibrium line altitude of Kongsvegen glacier $\left(78.76^{\circ} \mathrm{N} 13.16^{\circ} \mathrm{E} 537 \mathrm{~m}\right.$ asl; Figure 1). At this altitude, the accumulation period usually lasts from September until May, when up to $\sim 2 \mathrm{~m}$ of snow can accumulate. During winter and early spring the surface is virtually smooth except for wind-induced sastrugi. Surface roughness significantly increases during summer due to differential ice melt and the formation of surface melt water streams.

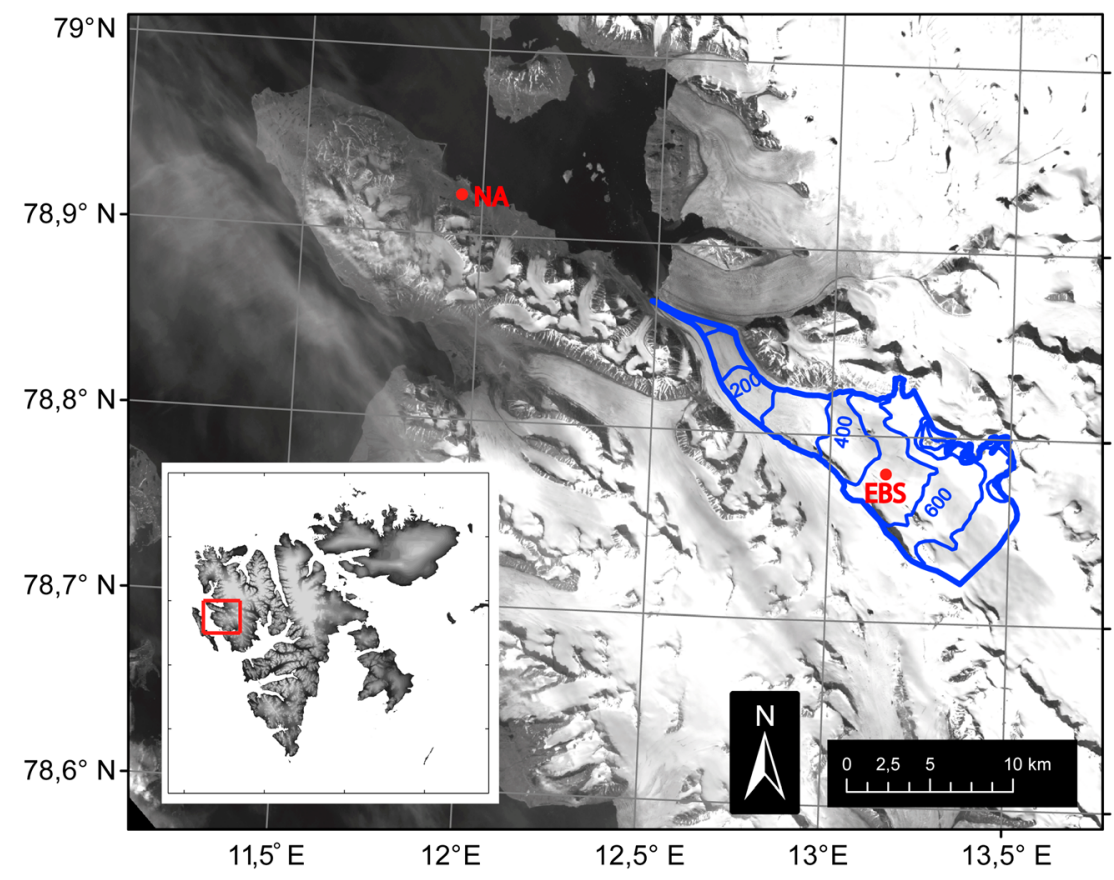

Figure 1. The location of Kongsvegen glacier in northwest Svalbard. Red dots indicate the position of the investigation site (EBS) and of Ny-Ålesund climate station (NA). The glacier outline and $100 \mathrm{~m}$ elevation contours are indicated in blue. (optical LandSat 7 image from July 1999; Aster DEM 30 m resolution). 


\section{Data}

[10] The EBS was operational since spring 2000, measuring air temperature, relative humidity, wind speed, and direction as well as the shortwave and longwave radiation components on a horizontal surface. Surface height changes were tracked with an ultrasonic ranger. The data were sampled every 2 min and hourly averages were stored onto Campbell loggers (CR10X, CR23X). Details about the sensors and their nominal accuracy are given in Table 1.

[11] Until 2007 the temperature/humidity sensor was housed in a naturally ventilated screen. The anticipated radiation error in the temperature measurements was corrected following Smeets [2006] employing a function of accumulated incoming and reflected shortwave fluxes and wind speed. A total of $66 \%$ of the hourly temperature records was corrected accordingly (during summer mainly) and induced a $0.7^{\circ} \mathrm{C}$ reduction of decadal temperatures compared to the uncorrected data. No corrections were applied afterward because the sensor was artificially ventilated during periods with solar insolation in excess of $50 \mathrm{~W} \mathrm{~m}^{-2}$. Relative humidity was corrected to account for the sensor measuring with reference to liquid water $(83 \%$ of the total record). As a result the decadal mean was increased by $\sim 4 \%$ and the corresponding impact on calculated vapor pressure was $+0.1 \mathrm{hPa}$. It is remarkable that the records of wind speed were virtually not affected by serious problems to icing, which is a common problem elsewhere. This is judged by the fact that we never recorded the propeller having not rotated during the scanning interval, i.e., an hour. Solar insolation data was checked regarding successive values of albedo beyond 0.95 , as is considered as an indicator of icing or snow deposition on the instrument domes. The gaps were filled calculating solar insolation based on assuming a correctly estimated reflected shortwave radiation and an albedo of 0.95 . The correction took effect for $22 \%$ of the measured data but traced on the decadal average in negligible extent $\left(+0.3 \mathrm{~W} \mathrm{~m}^{-2}\right)$. This correction also affects albedo which on average is decreased by $7 \%$. Incoming longwave radiation data was generally corrected for the window heating effects using a linear function of solar incoming radiation as suggested by the manufacturer. On average, the corrected data were $2 \mathrm{~W} \mathrm{~m}^{-2}$ lower than the uncorrected ones. Outliers were identified and replaced by comparison with values calculated according to König-Langlo and Augstein, 1994. Corrections concerned $66 \%$ of the record and lowered the decadal average by $-3 \mathrm{~W} \mathrm{~m}^{-2}$. Corrections for potential misalignment of the radiation sensors could not be applied due to the lack of reliable background information (tilt meter).

[12] A general gap resulted from a recurring failure of the power supply of certain sensors during the years 2005 and 2006 . In consequence $24 \%$ of the total record was closed by regression between variables measured at the glacier and at Ny-Ålesund climate station derived from concurrent and undisturbed measurements from both sites. For air temperature the skill of the inherent approach is encompassed by a bias of $-0.3^{\circ} \mathrm{C}\left(r^{2}=0.97\right)$, respective values for vapor pressure are $+0.5 \mathrm{hPa}\left(r^{2}=0.93\right),+2 \mathrm{~W} \mathrm{~m}^{-2}\left(r^{2}=0.9\right)$ for solar insolation, $+6 \mathrm{~W} \mathrm{~m} \mathrm{~m}^{-2}\left(r^{2}=0.85\right)$ for longwave incoming radiation and $+0.8 \mathrm{~m} \mathrm{~s}^{-1}\left(r^{2}=0.55\right)$ for wind speed. Despite of this overall good performance, the results from those years must be considered as the most uncertain ones in general. It may finally be noted as well that all these mentioned problems are common to measurements in polar environments, that some corrections could be done in a more sophisticated way as indicated by, e.g., van den Broeke et al. [2004] and that the documented uncertainties will be reconsidered in the sensitivity studies, too.

[13] Snow precipitation was derived from surface height changes measured by the sonic ranger. If the measured surface raised more than $1 \mathrm{~cm}$ within one hour, the precipitation amount was calculated using a parameterization of fresh snow density depending on air temperature [Anderson, 1976]. Hence, fresh snow density is set to $50 \mathrm{~kg} \mathrm{~m}^{-3}$ if air temperature is less than $-15^{\circ} \mathrm{C}(\sim 20 \%$ of the cases $)$, and increases toward $150 \mathrm{~kg} \mathrm{~m}^{-3}$ at $0^{\circ} \mathrm{C}$. The end winter snow heights and water equivalents were finally adjusted to the stake measurements in spring and autumn. Remaining gaps in the record were filled employing regression with Ny-Ålesund precipitation measurements, which also served to estimate precipitation in the form of rain.

[14] The station was visited twice a year for maintenance, data collection and acquisition of supporting data from snow pits (snow height, density and structure) and stakes (specific summer/winter mass balances). Snow accumulation and melt induced continual changes in actual height of the sensors above the surface. Typically, wind speed was measured $\sim 1.5$ $\mathrm{m}$ above the (snow) surface in spring and at about $3.5 \mathrm{~m}$ above

Table 1. Nominal Specifications of Instruments Used at the EBS Measurement Site During 2001-2010. Swiss-Teco Radiometers Were Used Prior to 2003 and Vaisala HMP45A Were Used Prior to 2007

\begin{tabular}{|c|c|c|}
\hline & Instrument & Nominal Accuracy \\
\hline \multirow[t]{2}{*}{ Temperature } & Vaisala HMP45A (unventilated shield) & $\pm 0.3^{\circ} \mathrm{C}$ \\
\hline & Rotronic Hygroclip (ventilated shield) & $\pm 0.1^{\circ} \mathrm{C}$ \\
\hline \multirow[t]{2}{*}{ Relative humidity } & Vaisala HMP45A (unventilated shield) & $\pm 3 \%$ \\
\hline & Rotronic Hygroclip (ventilated shield) & $\pm 1 \%$ \\
\hline Wind speed & Young Wind Monitor RM 05103 & $\pm 0.3 \mathrm{~ms}^{-1}$ \\
\hline \multirow[t]{2}{*}{ Incoming sw-radiation } & Swiss-Teco & $\pm 10 \%$ of daily sum \\
\hline & Kipp\& Zonen CNR1 & \\
\hline \multirow[t]{2}{*}{ Reflected sw-radiation } & Swiss Teco & $\pm 10 \%$ of daily sum \\
\hline & Kipp\& Zonen CNR1 & \\
\hline \multirow[t]{2}{*}{ Atmospheric lw-radiation } & Swiss Teco & $\pm 10 \%$ of daily sum \\
\hline & Kipp\& Zonen CNR1 & \\
\hline \multirow[t]{2}{*}{ Surface emitted lw-radiation } & Swiss Teco & $\pm 10 \%$ of daily sum \\
\hline & Kipp\& Zonen CNR1 & \\
\hline Snow height & Sonic Ranger SR $50 \mathrm{~L}$ & $\pm 0.4 \%$ \\
\hline
\end{tabular}


the (ice) surface in fall. Such varying measurement heights are considered in the evaluation of the turbulent fluxes.

\section{Model}

[15] Measured data are used to drive a model for calculating the mass and energy balance, which we then use to investigate the associated processes, model uncertainties and climate sensitivities. We use SOMARS (Simulation Of glacier surface Mass balance And Related Sub-surface processes) [Greuell and Konzelmann, 1994], whose original version and its offshoots have widely been used to calculate the point-distributed and spatially distributed surface energy balance on glaciers and ice sheets [Greuell and Oerlemans, 1987; Greuell and Genthon, 2003; Bougamont et al., 2005; Reijmer and Hock, 2008, van den Broeke et al., 2005]. The model is extensively described elsewhere [e.g., Greuell and Konzelmann, 1994; Reijmer and Hock, 2008] and we therefore give just a basic description and note important differences specific to this study.

[16] SOMARS is a one-dimensional model employing an atmospheric and a multilayer subsurface module. Thus the model calculates the energy and mass fluxes within each snow/ice grid cell by solving for the changes in temperature, water content and density at each grid element in the model domain

$$
\rho c_{p} \frac{\partial T}{\partial t}=\frac{\partial}{\partial z}\left(\lambda \frac{\partial T}{\partial z}\right)+\frac{\partial S E B}{\partial z}-L_{m} M R+L_{f} F R
$$

[17] Thus, temperature $(T)$, density $\left(\rho=910 \mathrm{~kg} \mathrm{~m}^{-3}\right)$ and the heat capacity of ice $(c)$ determine changes of the cold content within layers of thickness $\mathrm{d} z$ (left-hand term), molecular heat conduction (first right-hand term) is determined by effective thermal conductivity ( $\lambda$, parameterized as a function of density) and energy exchanges due to phase changes (third and fourth right-hand terms), which are driven by the melt and freezing rates $(M R$ and $F R)$, respectively. Note that exchange of energy with the atmosphere (SEB, see equation (2)) is restricted to the uppermost grid cell, except for shortwave radiation which partly can penetrate and be absorbed below the surface as well. The relevant part of the spectrum is discriminated by wavelengths smaller than $0.8 \mu \mathrm{m}$ (assumed to constitute $75 \%$ of total intensity) and its layer-wise absorption is parameterized by Beer's law approach. Absorption coefficients are prescribed for ice or slush and are parameterized for snow employing a linear function of snow density to account for changes in response to snow metamorphism. Excess energy in a grid cell is used for melt and refreezing occurs as long as liquid water is present and temperature is below $0^{\circ} \mathrm{C}$. The rather basic treatment of radiation extinction is probably a shortcoming of this model as well as addressing surface fluxes to a finite layer instead of referring to a model skin layer as was recently pointed out by Kuipers Munneke et al. [2012].

[18] The model also calculates the total energy being available at the surface (SEB), which is determined by the sum of net radiation (NR, constituted by shortwave and longwave components), turbulent sensible heat flux (SHF), latent heat flux (LHF) and heat provided by rain (R)

$$
\mathrm{SEB}=\mathrm{NR}+\mathrm{SHF}+\mathrm{LHF}+R
$$

[19] These terms are partly determined by the forcing parameters (air temperature, humidity, wind speed, shortwave radiation components, longwave incoming radiation and precipitation) while being coupled to the subsurface module through the surface grid element on the other hand (turbulent fluxes and longwave emitted radiation).

[20] The mass balance of a grid cell (MB) is forced by accumulation $(\mathrm{P})$ and coupled to the energy balance through the condensation/evaporation rate $(\mathrm{CE})$ and runoff $(\mathrm{Ro})$

$$
\mathrm{MB}=P \pm \mathrm{CE}-\mathrm{Ro} .
$$

[21] All fluxes are given in units $\mathrm{W} \mathrm{m}^{-2}\left(\mathrm{~kg} \mathrm{~m}^{-2} \mathrm{~s}^{-1}\right)$ and defined positive when providing mass or energy to a model layer. Turbulent fluxes are calculated by a bulk approach based on the Monin-Obukov frame work and stability functions proposed by Högström [1988]. Iterative calculation of surface temperature is a key issue in this context involving the temperature gradients in the two uppermost grid cells, surface emitted radiation and the turbulent fluxes. The model treats variable momentum roughness length depending on the surface type. Lacking appropriate measurements, the initial values are set according to Denby and Smeets [2000] at $2 \mathrm{~mm}$ (frozen snow), $4 \mathrm{~mm}$ (melting snow) and $8 \mathrm{~mm}$ (ice). Scalar roughness lengths are parameterized following Andreas [1987].

[22] SOMARS calculates the vertical profiles of temperature, density and water content. The model simulates the most relevant snow processes although it does not explicitly treat grain size or snow microstructure. Thus, rain or melt water can penetrate or refreeze within the deeper layers of the snowpack. Water transport is parameterized by a gravitational scheme and irreducible water content specified as a function of porosity according to Coléou and Lesaffre [1998]. Upon exceeding the latter threshold $(<10 \%)$, water can progressively percolate through the snowpack until reaching saturated or impermeable layers (ice). At that point, SOMARS accounts for fractional runoff based on a parameterization by Zuo and Oerlemans [1996]. This also treats the eventual formation of slush layers or the formation of super-imposed ice depending on the surface slope and an adjustable runoff time scale. Notably the latter was increased from 3.7 days [Zuo and Oerlemans, 1996] to 8 days, while other studies used smaller values [Reijmer and Hock, 2008]. This calibration was based on consideration of intermittent observations of the depth of superimposed ice and conforms to former evidence that at the elevation of EBS runoff from slush layers can effectively be strongly prohibited due to the locally flat topography. This can even result in intermittent formation of lakes as was observed by Obleitner and Lehning [2004] during the year 2000.

[23] Preliminary runs showed that the originally implemented parameterization of snow densification underestimated the observed settling rates at the Kongsvegen investigation site [Erath, 2005; Krismer, 2009]. Therefore, the according routine was replaced and densification is now driven by overburden pressure and temperature-dependent snow metamorphism following Jordan [1991]. Enhanced settling at high liquid water contents is not considered thereby.

\section{Model Set Up and Initialization}

[24] SOMARS is driven by hourly averages of incoming shortwave radiation, albedo, atmospheric longwave radiation, air temperature, humidity, wind speed and precipitation 
measured at EBS from 2000 until 2010. The initial grid comprises $50 \mathrm{~m}$ of ice and $1.4 \mathrm{~m}$ of snow with an average density of $400 \mathrm{~kg} \mathrm{~m}^{-3}$, the latter representing the observations in spring 2000. The initial grid spacing increases from $0.04 \mathrm{~m}$ at the surface to $5 \mathrm{~m}$ at the bottom of the domain. The number of grid cells and their spacing change during the calculations in response to accumulation, densification, and melt. The initial temperature profile was developed by a spin-up run based on earlier borehole data measured at 367 and $635 \mathrm{~m}$ asl [Björnsson et al., 1996]. Accordingly, a constant temperature of $-4.9^{\circ} \mathrm{C}$ was prescribed at the bottom grid cell. The time step of the numerical simulation is one minute and average hourly output is analyzed further.

\section{Results and Discussion}

\subsection{Model Validation}

[25] Validation of the simulation results is performed with measured surface temperature, snow density and snow/ice thickness changes. Figure 2 (top) demonstrates that the simulation skillfully reproduces the temporal development of surface height changes $\left(r^{2}=0.96\right.$, root-mean-square error $($ RMSE $)=0.2 \mathrm{~m})$. The validating data from the sonic ranger are representative for a surface area of $\sim 80 \mathrm{~cm}^{2}$ and have an accuracy of $\pm 0.4 \%$ of the reading (Table 1 ). An equally good skill is given with respect to the stake measurements, which represent the cumulative end winter and summer conditions $\left(r^{2}=0.98\right.$ and within $\left.\operatorname{RMSE}=0.2 \mathrm{~m}\right)$.

[26] Modeling snow height involves also the treatment of densification, i.e., snow metamorphism processes. Figure 2 (lower left) shows that the observed density profiles are well captured by the simulations, both in terms of the magnitude and the vertical gradient. Hence, the cumulative specific surface mass balance is skillfully simulated as well (observation: $-1857 \mathrm{~mm}$ vs. simulation $-1822 \mathrm{~mm} \mathrm{w}$. eq.), impressive given that spatial representativeness of stake and snow pit measurements is limited [Obleitner, 2000; Kaser et al., 2003; Hawley et al., 2008].

[27] Surface temperature is a key output variable involved in several flux parameterizations and calculation steps. Figure 2 (lower right) depicts a good skill of the model results compared to values computed from observations of upwelling longwave radiation $\left(r^{2}=0.95\right.$, RMSE $\left.=2.9^{\circ} \mathrm{C}\right)$. Closer inspection shows that the simulations perform slightly worse during summer compared to winter $\left(r^{2}=0.93 / \mathrm{RMSE}=3.3^{\circ} \mathrm{C}\right.$ vs. $0.97 / 1.8^{\circ} \mathrm{C}$ ). In part, the discrepancy must be attributed to measurement uncertainties related to remaining window heating effects of the downfacing pyrgeometer, which implies that the effective accuracy is likely to be worse than $\pm 1^{\circ} \mathrm{C}$ [Obleitner and De Wolde, 1999]. Further uncertainty may be associated to, e.g., undetected riming of the sensor or uncorrected tilt effects. However, the deviations may also stem from diverse model uncertainties. Such may be related to relevant parameterizations (turbulent fluxes mainly) or to deficiencies in the used numerical methods (by, e.g., calculating surface temperature via linear extrapolation from the uppermost two grid cells). The observed deviations are likely due combined effects. An in depth investigation of error sources by, e.g., targeted sensitivity studies is beyond the scope of this study but will be addressed in future studies. At least, however, this validation quantifies the gross uncertainty and basically supports that most relevant mass and energy balance processes are properly treated in the simulations.

\subsection{Meteorological Conditions}

[28] General weather conditions in the Kongsvegen environment and the representativeness of the investigated decade may be described by data from the nearest climate station located ca. $25 \mathrm{~km}$ to the west of the glacier (Ny-Ålesund, $78^{\circ} 55^{\prime} \mathrm{N}, 11^{\circ} 56^{\prime} 11 \mathrm{E}, 11 \mathrm{~m}$ asl). According to Førland et al. [2011] the WMO normal period 1961-1990 was characterized by a mean annual temperature of $-6.3^{\circ} \mathrm{C}$ and an annual precipitation of $385 \mathrm{~mm}$. Snow or rain can occur

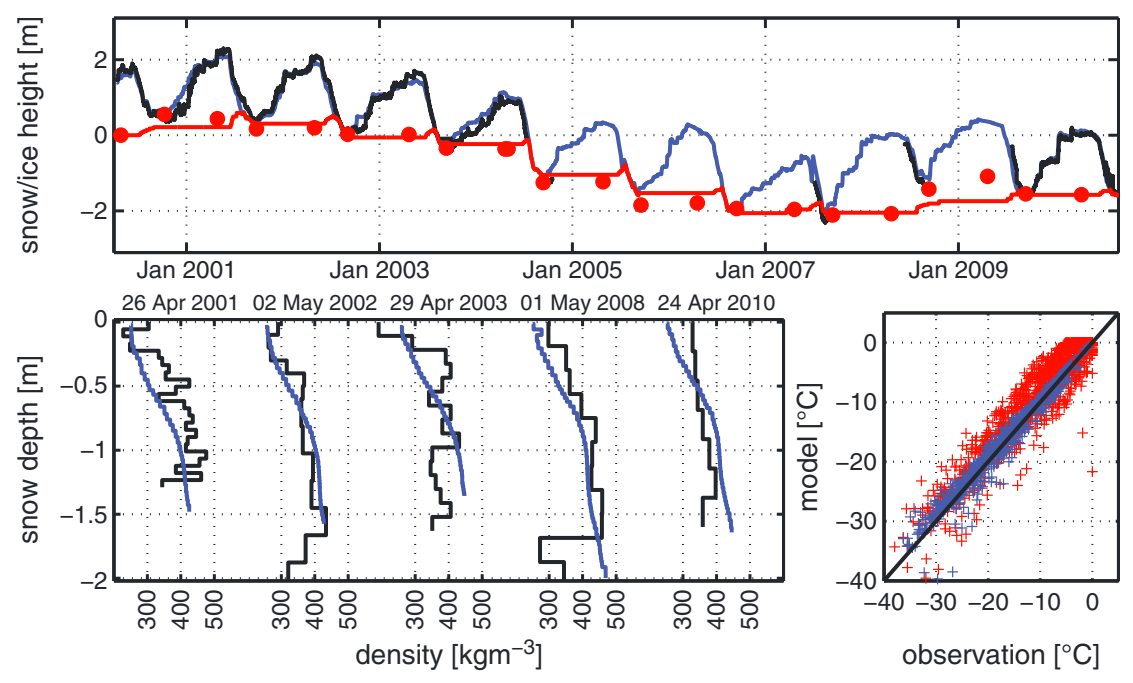

Figure 2. (top) Simulated surface height (blue) compared to observations (black) and height of the calculated snow/ice interface (red curve) compared to stake readings (red dots). Zero height refers to the snow/ice interface observed in spring 2000. (bottom) Comparison of measured (black) and simulated (blue) snow density profiles and validation of mean daily surface temperature (right) during the ablation season (JJA, red crosses) and the accumulation season (remaining months, blue crosses), respectively. 
during any month of the year. There is a prevalence of southeasterly lower atmosphere winds, which is particularly pronounced during autumn and winter, when the main precipitation events occur. Mean annual air temperature during the investigated period was $-4.1^{\circ} \mathrm{C}$ (2001-2010), significantly warmer than the temperature during the decades before. Precipitation during the investigation period was about equal to the long-term average $(363 \mathrm{~mm})$.

[29] A summary of the average meteorological parameters and the energy balance components is given in Table 2, thereby distinguishing a mean ablation period (JJA) and accumulation period (the remaining months). Figure 3 shows the variability of these parameters for various time scales (monthly, diurnal, interannual). The decadal meteorological conditions at EBS are basically characterized by an average air temperature of $-9.3^{\circ} \mathrm{C}$, high relative humidity $(90 \%)$, and wind speeds of $4.6 \mathrm{~m} \mathrm{~s}^{-1}$. Air temperature can be positive during any month of the year, which is remarkable for winter at this high latitude. The latter reflects enhanced synoptic influence, which frequently disturbs the stably stratified glacier boundary layer formed during calm weather. In summer, air temperature settles close to $0^{\circ} \mathrm{C}$ due to the damping influence of melt at the glacier surface. The average diurnal cycle of air temperature is weak $\left(<2^{\circ} \mathrm{C}\right)$ and slightly enhanced during winter (Figure 3 ). Ny-Ålesund shows an even smaller diurnal cycle $\left(0.7^{\circ} \mathrm{C}\right)$, reflecting its coastal site. Mean annual air temperature ranges from $-11.2^{\circ} \mathrm{C}(2003)$ to $-7.6^{\circ} \mathrm{C}(2006)$. Analysis of the daily temperature patterns indicates that these extreme years were mainly influenced by abnormal winter conditions. Comparison to Ny-Ålesund yields pseudovertical temperature gradients close to the dry adiabatic lapse rate $\left(-0.0099^{\circ} \mathrm{C} \mathrm{m}^{-1}\right)$ with somewhat smaller values during summer $\left(-0.0087^{\circ} \mathrm{C} \mathrm{m}^{-1}\right)$. Obleitner and Lehning [2004] suggest that this can be attributed to the seasonal variability of sea ice in the fjord. Based on our 10 year record, a tendency toward somewhat higher temperatures at the end of the decade can be found ( $p=3 \mathrm{E}-8, \alpha=0.05$ ).

[30] Relative humidity is generally high ( $>90 \%)$, particularly in winter (Table 2). Values are lower by about $5 \%$ during summer and noon, respectively. The generally small variability in relative humidity implies that the development of vapor pressure is closely correlated to air temperature (Figure 3). This induces a large seasonal variation in vapor pressure with low values during winter $(2.5 \mathrm{hPa})$ while values can exceed $6.1 \mathrm{hPa}$ during summer. The day-to-day variability also resembles the pattern of temperature (not shown). The year 2003 was characterized by particularly low vapor pressure, while 2006 and 2009 were comparatively moist (Figure 3 ). The average diurnal cycle of atmospheric vapor pressure is smaller than $0.5 \mathrm{hPa}$.

[31] Average wind speeds are higher and more variable during winter, when hourly averages frequently exceed $10 \mathrm{~m} \mathrm{~s}^{-1}$. In general, wind speed does not correlate with air temperature and there is no significant diurnal variation of wind speed on an annual basis and during winter. However, there is a weak diurnal cycle during summer, as seen elsewhere [Klok et al., 2005; van den Broeke et al., 2006], which is related to weaker upper air winds and enhanced katabatic forcing. Annual averages range from 4.3 to $4.9 \mathrm{~m} \mathrm{~s}^{-1}$.

[32] Figure 4 shows the typical frequency distribution of wind directions observed at the glacier. The pattern is characterized by a high directional constancy $(0.42)$ and a prevalence of strong southeasterly winds (down-slope), especially frequent during winter. The latter winds are primarily associated with katabatic forcing and topographically modified synoptic winds that come prevailingly from the east [Kupfer et al., 2006 The SE-NW alignment of the major mountain ranges also plays a role (Figure 1). We note another peak wind direction in the northeasterly direction, which reflects another topographic gap in the upper glacier basin.

[33] Modeling studies by, e.g., Sandvik and Furevik [2002], Stütz [2010], or Esau and Repina [2012] suggest that glacier winds can influence the wind conditions at Ny-Ålesund, 25 $\mathrm{km}$ to the northwest of Kongsvegen (Figure 1). This is corroborated by our observational data (Figure 4, upper right panel), which clearly reflect the general orientation of Kongsfjorden orography and the prevalence of winds from the glacierized areas to the east. The relatively frequent winds from southerly directions are explained as down-slope winds draining along the slopes of the Zeppelin mountain range south of Ny-Ålesund or glacier winds from Austre Broggerbreen (Figure 1).

[34] Solar radiation is a major driver for local meteorological conditions in general. Kongsvegen experiences polar night from October until February and abundant solar insolation during the central summer months, when a pronounced daily

Table 2. Average Meteorological Variables as Well as Energy Balance and Mass Balance Components (2001-2010). ABL Denotes the Ablation Period (JJA) and ACC the Accumulation Period, i.e., the Remaining Months. Abbreviations Follow Equation (1) and (3), Respectively. Note That Accumulation Includes Refrozen Melt Water (Superimposed Ice)

\begin{tabular}{|c|c|c|c|c|c|c|c|}
\hline & MEAN & $\mathrm{ACC}$ & $\mathrm{ABL}$ & & MEAN & $\mathrm{ACC}$ & $\mathrm{ABL}$ \\
\hline Air temperature $\left[{ }^{\circ} \mathrm{C}\right]$ & -9.3 & -12.5 & 0.0 & $\mathrm{NR}\left[\mathrm{Wm}^{-2}\right]$ & -1.1 & -13.8 & 36.6 \\
\hline Rel. humidity [\%] & 90.4 & 91.2 & 88.1 & SHF $\left[\mathrm{Wm}^{-2}\right]$ & 9.2 & 9.8 & 7.5 \\
\hline Vapor pressure $[\mathrm{hPa}]$ & 2.5 & 1.9 & 5.4 & LHF $\left[\mathrm{Wm}^{-2}\right]$ & 1.4 & 2.6 & -1.9 \\
\hline Surface temperature $\left[{ }^{\circ} \mathrm{C}\right]$ & -10.0 & -13.2 & -1.0 & $\mathrm{R}\left[\mathrm{Wm}^{-2}\right]$ & 0.0 & 0.0 & 0.0 \\
\hline Surface vapour pressure $[\mathrm{hPa}]$ & 2.5 & 1.8 & 5.6 & SEB $\left[\mathrm{Wm}^{-2}\right]$ & 9.5 & -1.4 & 42.2 \\
\hline Wind speed $\left[\mathrm{ms}^{-1}\right]$ & 4.6 & 5.0 & 3.3 & residual $\left[\mathrm{Wm}^{-2}\right]$ & $<0.1$ & $<0.1$ & $<0.1$ \\
\hline sw-incoming radiation $\left[\mathrm{Wm}^{-2}\right]$ & 93.3 & 52.4 & 214.0 & & & & \\
\hline sw-reflected radiation $\left[\mathrm{Wm}^{-2}\right]$ & 70.5 & 42.8 & 151.5 & accumulation $[\mathrm{m}]$ & 6.7 & 5.7 & 1.0 \\
\hline Albedo & 0.75 & 0.82 & 0.71 & rain $[\mathrm{m}]$ & 0.2 & 0.1 & 0.1 \\
\hline lw-incoming radiation $\left[\mathrm{Wm}^{-2}\right]$ & 246.4 & 233.2 & 285.2 & cond /evap [m] & 0.1 & 0.2 & -0.1 \\
\hline lw-emitted radiation $\left[\mathrm{Wm}^{-2}\right]$ & 270.4 & 256.6 & 311.2 & total gain $[\mathrm{m}]$ & 7.1 & 6.1 & 1.0 \\
\hline Net sw radiation $\left[\mathrm{Wm}^{-2}\right]$ & 22.9 & 9.6 & 62.5 & runoff $[\mathrm{m}]$ & 8.9 & 0.6 & 8.3 \\
\hline Net lw radiation $\left[\mathrm{Wm}^{-2}\right]$ & -24.0 & -23.4 & -26.0 & mass balance $[\mathrm{m}]$ & -1.8 & 5.5 & -7.3 \\
\hline
\end{tabular}


KARNER ET AL.: KONGSVEGEN ENERGY AND MASS BALANCE

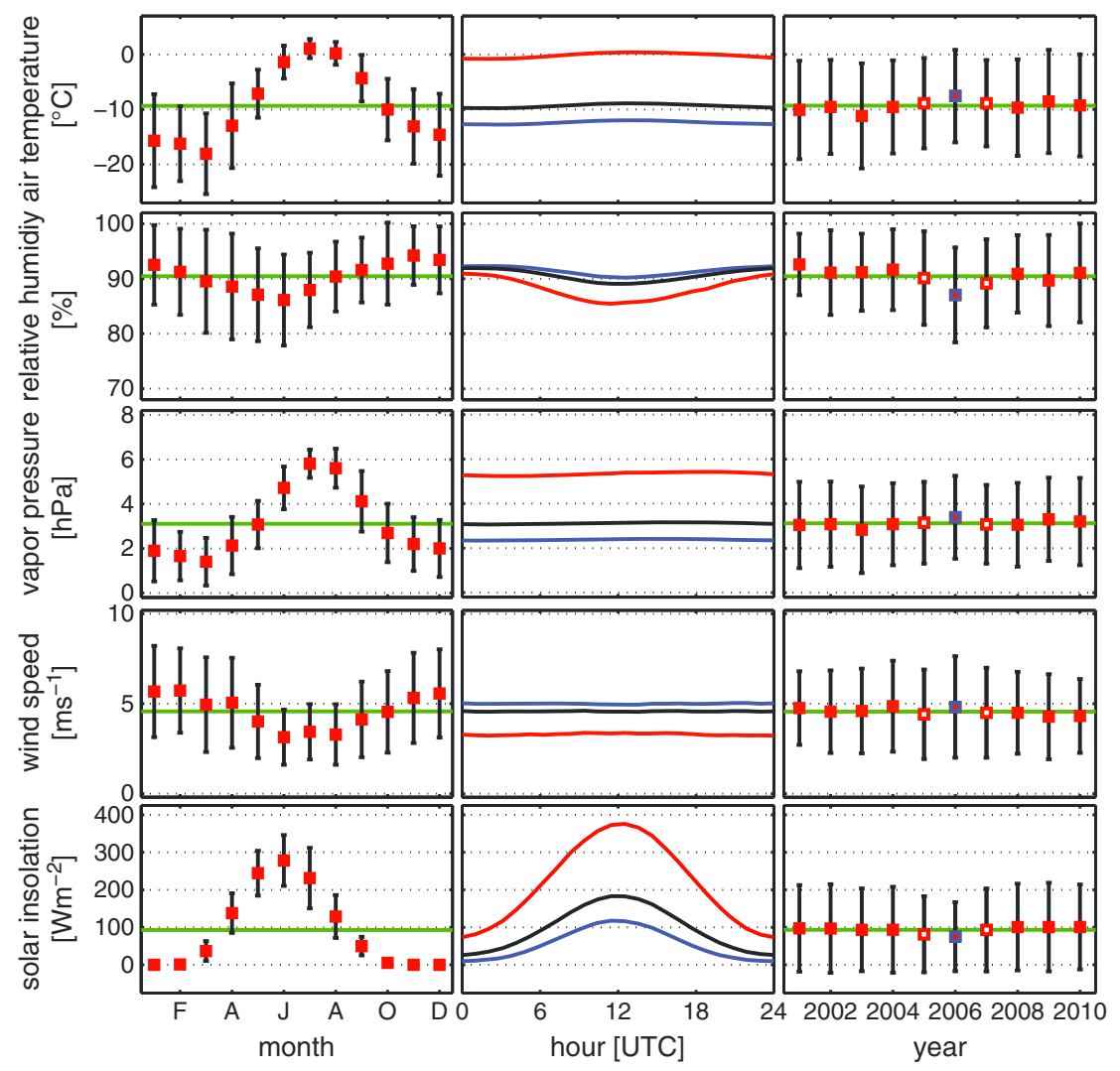

Figure 3. (left) Mean monthly meteorological variables observed at Kongsvegen EBS during the investigated decade. Red squares indicate arithmetic mean values and vertical bars denote standard deviations. (middle) Mean diurnal cycles for the full decade (black), the ablation period (red) and the accumulation period (blue). (right) Mean annual values (red dots) with vertical bars denoting standard deviations and green line denoting the decadal average. The filled red squares indicate that less than $33 \%$ of the annual data were derived from regression with Ny-Ålesund data, compared to $33 \%$ to $66 \%$ for open red squares and more than $66 \%$ for open blue squares, respectively.

cycle is apparent, too (Table 2 and Figure 3). Average annual broadband atmospheric transmissivity is 0.44 , and is higher in summer due to less cloudiness. Ny-Ålesund experiences lower atmospheric transmissivity $(0.36)$ reflecting more clouds or fog and enhanced aerosol content due to the additional air mass and the more maritime, i.e., coastal environment [Kupfer et al., 2006]. The summers 2005 and 2006 stand out as having especially low solar insolation (Figure 3). These years, and especially their summers, are characterized by relatively high air temperatures, high humidity and enhanced atmospheric longwave radiation, all of which are linked to unusual synoptic activity.

\subsection{Surface Energy Balance}

[35] At the measurement site about $44 \%$ of the extraterrestrial insolation reaches the surface, where $75 \%$ is reflected. Albedo ranges from 0.82 to 0.71 during the accumulation period and ablation period (Table 2). The associated transition from snow to ice starts in May, with bare ice usually appears in late June. Figure 5 shows that on average the lowest monthly values of albedo (0.60) occur in August, a month after the maximum intensity of net shortwave radiation. There is a negligible diurnal variation of the average surface reflectivity $( \pm 5 \%)$. However, the summer and clear days are characterized by significantly lower noon time values, as is expected from theoretical considerations and observations elsewhere [Warren and Wiscombe, 1980; Arendt, 1999]. Figure 5 also reveals a striking interannual variation of surface reflectivity. Thus the years 2001-2006 stand out with below average values of surface reflectivity, while albedo remains high afterwards. These features are strongly determined by the summer conditions and the associated impact on net radiation has implications for the mass balance of the glacier, as will be shown later.

[36] The longwave radiation budget is negative on average $\left(-24 \mathrm{~W} \mathrm{~m}^{-2}\right)$, as is usual above snow and ice surfaces. Seasonal variations are characterized by enhanced losses during early summer (Table 2, Figure 5). This is mainly linked to more cloud-free days as is observed at Ny-Ålesund [Kupfer et al., 2006]. The average diurnal variation is characterized by stronger longwave radiation losses during noon time (Figure 5). Annual values of the longwave radiation budget during the investigated decade ranges from -29 to $-16 \mathrm{~W} \mathrm{~m}^{-2}$. The least negative values occurred in 2006 and 2007, among the warmest years of the investigated period.

[37] The decadal average of net radiation was slightly negative $\left(-1.1 \mathrm{~W} \mathrm{~m}^{-2}\right)$. An enhanced radiation deficit is observed during the accumulation period (winter), while the glacier surface experiences a significant gain during the 

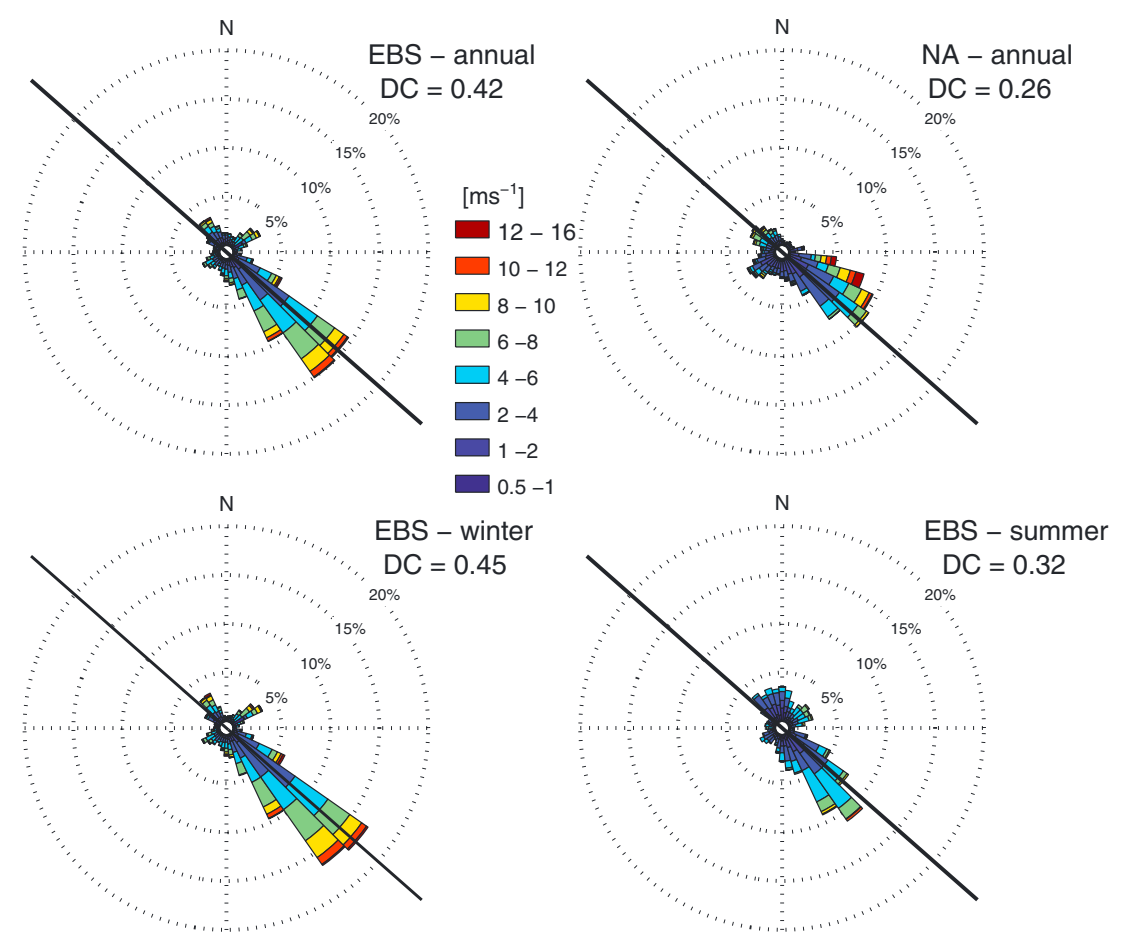

Figure 4. (top) Mean annual wind direction frequency distributions measured at Kongsvegen EBS during 2004 (left) and at Ny-Ålesund climate station (right) with corresponding directional constancy (DC). (bottom) Mean annual wind direction frequency distributions measured at Kongsvegen EBS during winter (left) and summer (right). The black line indicates the glacier and fjord direction.

melt period (Table 2). Net radiation is positive from May until October due to strong shortwave input. The average diurnal cycle of net radiation is pronounced throughout the year. During the melt season solar insolation keeps net radiation positive throughout almost the entire day, while during the accumulation season net radiation is negative during the entire diurnal cycle. Figure 5 shows a considerable variability of net radiation from year to year ranging from $+7 \mathrm{~W} \mathrm{~m}^{-2}$ (2006) to $-9 \mathrm{~W} \mathrm{~m}^{-2}$ (2008), both being strongly determined by the shortwave balance, i.e., albedo.

[38] The overall small loss of energy by radiation on the decadal-scale was compensated by effective energy input from the turbulent fluxes (sensible and latent) providing $+10.6 \mathrm{~W} \mathrm{~m}^{-2}$ on average. This energy was used to melt and warm up the ice throughout the investigated decade. The input from the turbulent fluxes is also the only source of energy during the accumulation period (winter). At this time, however, more energy is lost through the strongly negative radiation balance, which leads to an overall negative energy balance. Conversely, the energy balance is strongly positive during the ablation period $\left(+42 \mathrm{~W} \mathrm{~m}^{-2}\right)$ due to the combined input by net radiation $\left(+37 \mathrm{~W} \mathrm{~m}^{-2}\right)$ and turbulent sensible heat transfer $\left(+7 \mathrm{~W} \mathrm{~m}^{-2}\right)$. This gain is slightly reduced by the negative latent heat flux at that time of the year $\left(-2 \mathrm{~W} \mathrm{~m}^{-2}\right)$.

[39] Figure 5 shows that the average sensible heat flux changes sign during May and June. This corresponds to unstable atmospheric temperature stratification instead of the otherwise prevailing inversion conditions. During these months the snow cover at the measurement site is still cold, air temperatures have only moderately increased, but solar insolation is already high. This favors high surface temperatures due to strong absorption of shortwave radiation in the near surface snow layers and comparatively ineffective conduction into the deeper snow layers [Cullen and Steffen, 2001; Obleitner et al., 2007; Kuipers Munneke et al., 2009]. The effect diminishes as soon as melt sets on and excess energy can no more be used to warm the snow. The average diurnal cycle of sensible heat flux is characterized by a noontime minimum, reflecting a weakening of the temperature inversion by solar heating of the surface. The interannual variation of sensible heat ranges from $+6 \mathrm{~W} \mathrm{~m}^{-2}$ (2001) to $+13 \mathrm{~W} \mathrm{~m}^{-2}$ (2004, 2005, and 2010).

[40] The average latent heat flux constitutes a weak source of energy $\left(+1.4 \mathrm{~W} \mathrm{~m}^{-2}\right)$ corresponding to net condensation of water vapor at the surface (Figure 5). This is most pronounced in winter when the surface strongly cools and synoptic events often advect relatively warm and moist air masses along the glacier. The months April to June are characterized by evaporation and an associated loss of energy from the surface. The interannual variation of the latent heat flux ranges from about $+4 \mathrm{~W} \mathrm{~m}^{-2}$ (2004) to $-3 \mathrm{~W} \mathrm{~m}^{-2}$ (2006) and resembles the development of sensible heat flux.

[41] The total of these fluxes drives the changes of the heat content of the near-surface snow or ice layers, and determines whether melt or freeze occur (equation (1). It was shown that a surplus of energy was available on a decadal average $\left(+9.5 \mathrm{~W} \mathrm{~m}^{-2}\right)$. The surface energy balance was particularly positive during the central summer months $\left(+42.2 \mathrm{~W} \mathrm{~m}^{-2}\right)$ and was slightly negative during the remaining months $\left(-1.4 \mathrm{~W} \mathrm{~m}^{-2}\right)$. The summer months also experienced a pronounced daily cycle of the energy balance, which is not observed in winter. Figure 6 (top) summarizes the year-to-year 


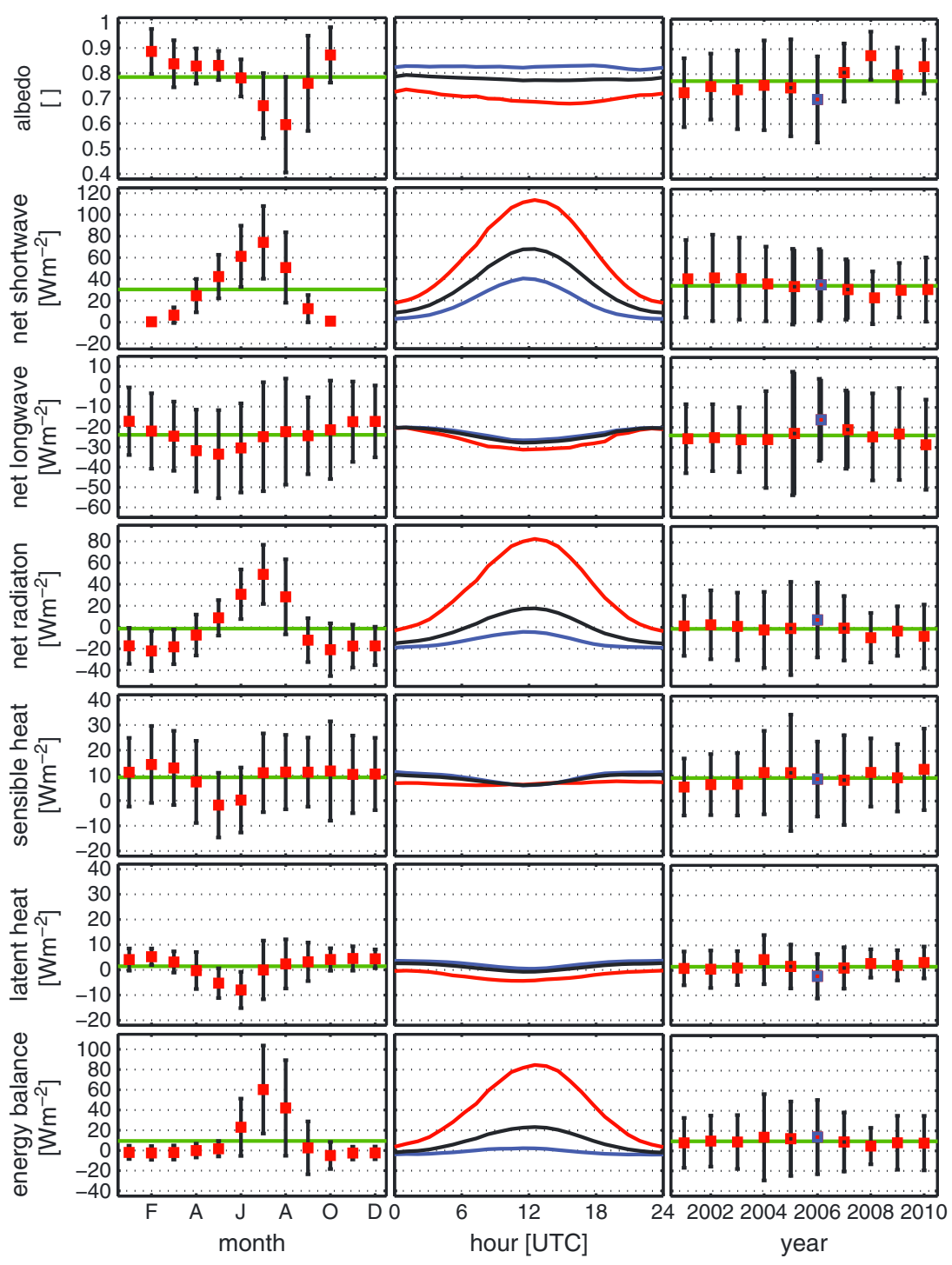

Figure 5. (left) Mean monthly energy balance components calculated for Kongsvegen EBS during the investigated decade. Red squares indicate arithmetic mean values and vertical bars denote standard deviations. (middle) Mean diurnal cycles during the full decade (black), ablation period (red) and accumulation period (blue). (right) Mean annual values (red dots) with vertical bars denoting standard deviations and green line denoting the decadal average. The filled red squares indicate that less than $33 \%$ of the annual data were derived from regression with Ny-Ålesund data, compared to $33 \%$ to $66 \%$ for open red squares and more than $66 \%$ for open blue squares, respectively.

variability of the energy balance components and shows that most energy was available during the years 2004 until 2006 $\left(\max .+14 \mathrm{~W} \mathrm{~m}^{-2}\right.$ ). Recall that these years were characterized by high summer temperatures, less negative longwave radiation budget and enhanced sensible heat fluxes. The glacier experienced strongly negative mass balances during these years. The mass balance year 2008 was characterized by strong accumulation input which in combination with an outstandingly low amount of available energy $\left(+5 \mathrm{~W} \mathrm{~m}^{-2}\right)$ lead to a positive mass balance at the investigation site (Figure 6 , bottom).

[42] These results confirm to previously published figures on energy balance components at Kongsvegen [Obleitner and Lehning, 2004; Erath, 2005; Krismer, 2009; Greuell et al., 2007], which are based on subsets of the data presented here. In lack of further data at the glacier itself, it is interesting to compare our data with the conditions at a permafrost site near $\mathrm{Ny}$-Ålesund [Westermann et al., 2009]. Annual net radiation is slightly positive there $\left(+4 \mathrm{~W} \mathrm{~m}^{-2}\right)$, which is mainly due to lower albedo in summer $(15 \%)$. Sensible heat flux is positive $\left(+7 \mathrm{~W} \mathrm{~m}^{-2}\right)$ while latent heat flux is slightly negative $\left(-7 \mathrm{~W} \mathrm{~m}^{-2}\right)$. The latter is significantly enhanced during summer $\left(-11 \mathrm{~W} \mathrm{~m}^{-2}\right)$, reflecting the influence of vegetation (transpiration).

\subsection{Snow Conditions, Glacier Mass Balance and Related Processes}

[43] The simulations permit investigation of the detailed evolution of snow and ice at the Kongsvegen measurement site during the decade 2001 to 2010. Figure 7 shows the 
KARNER ET AL.: KONGSVEGEN ENERGY AND MASS BALANCE

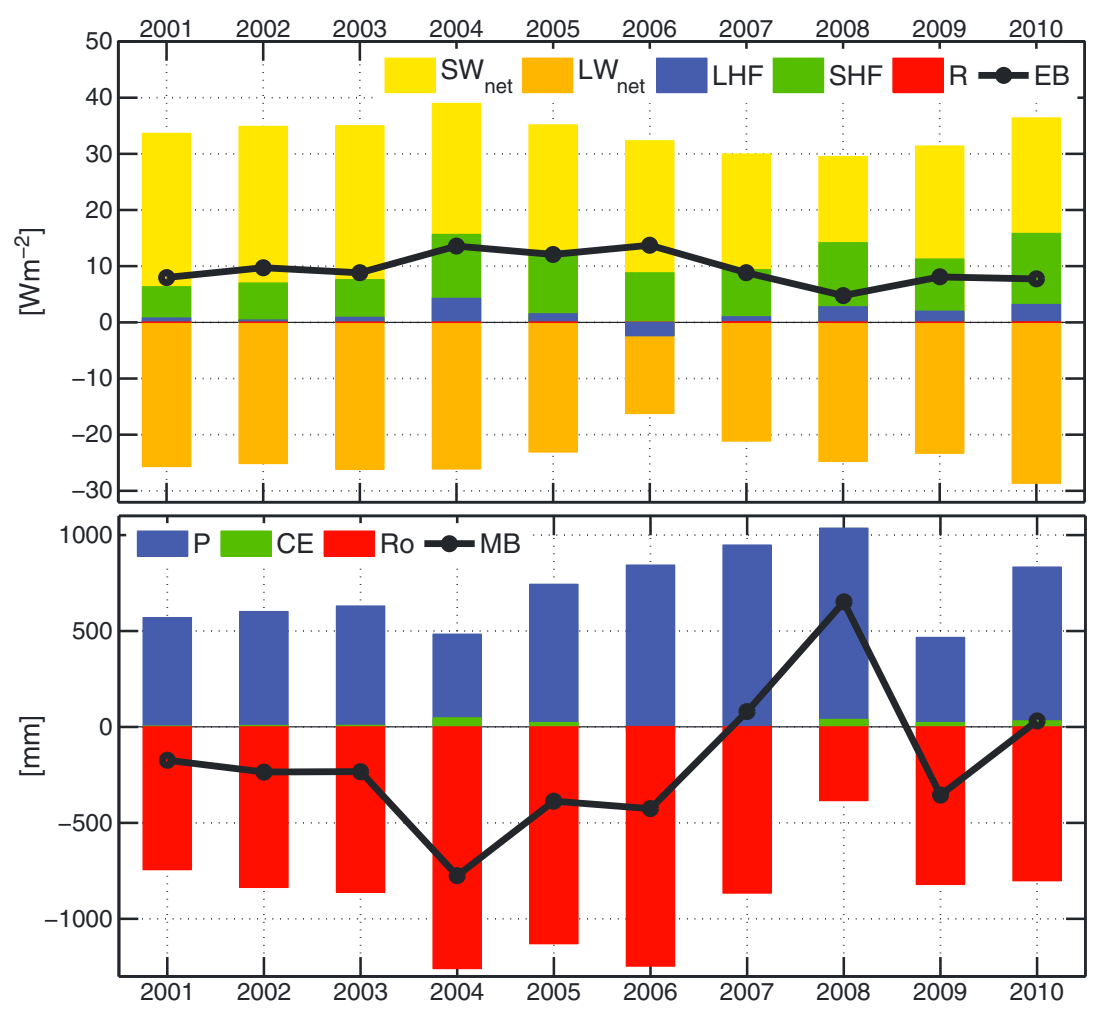

Figure 6. (top) Mean annual energy balance and (bottom) mass balance components. For abbreviations refer to equation (2) and to the text.

regular build-up of the snowpack during the accumulation period (October until April). Maximum snow height ranges from $1.4 \mathrm{~m}$ (2004 and 2005) to $2.2 \mathrm{~m}$ (2008) in April/May. Usually, about one third of the accumulated snow comes from a few major precipitation events in early winter, while the rest is composed from many and less efficient events throughout the winter. The average snow density by the end of winter is $380 \mathrm{~kg} \mathrm{~m}^{-3}$ and shows only a small variability from year to year (Figure 2). The surface height changes also reflect effects of settling due to snow metamorphism and melt. After major snowfalls and during the initial melt period (May), the surface typically lowers by about $1 \mathrm{~cm} \mathrm{~d}^{-1}$. Enhanced surface changes are observed in June $\left(\sim 4 \mathrm{~cm} \mathrm{~d}^{-1}\right)$ when the snowpack is soaked by melt water inducing enhanced snow metamorphism and runoff finally.

[44] The snowpack is normally melted away by late July to expose bare ice. This is expected at a site lying somewhat below the equilibrium line of the glacier. The average length of the ablation period is 80 days, ranging from 46 (2007) to 90 days (2006). Ice ablation usually starts in August and is initially characterized by an average rate of about $3 \mathrm{~cm} \mathrm{~d}^{-1}$ and diminishes due to the progressively limited amounts of melt energy. This development also induces the aforementioned changes in albedo and surface roughness. In total, the glacier ice surface lowered by $-1.6 \mathrm{~m}$ from 2000 to 2010 , consistent with the overall negative mass balance during the decade. The most negative mass balances occurred during the years 2004-2006.

[45] Figure 7 reveals more details about the physical processes within the snowpack and the underlying ice. Note for instance the progressive infiltration of surface meltwater during early summer. Runoff begins when meltwater reaches the impermeable ice surface of the previous year. However, there is an intermittent increase of water in the bottom snow layers due to fractional retention of meltwater. This eventually leads to the formation of a slush layer (yellow and red areas in Figure 7, central panel), as confirmed by earlier observations and model studies [Obleitner and Lehning, 2004] and remote sensing [Greuell et al., 2007; Brandt et al., 2008]. Further development involves formation of superimposed ice forming on top of the previous year's ice layer due to refreezing of meltwater upon contact with cold glacier ice. Normally, this superimposed ice builds up to a layer with a thickness of about $0.2 \mathrm{~m} \mathrm{w}$. eq., which is then melted during the later ablation period. This corresponds to about $27 \%$ of total accumulation. In some cases melt progresses further into ice from previous years (2003 until 2007). During the other years, however, more substantial bodies of superimposed ice developed $(\sim 0.5 \mathrm{~m})$, which partially survived the melt period and were buried by next year's snow accumulation (2001, 2007 until 2010). Obleitner and Lehning [2004] showed that the formation of such big bodies of superimposed ice is related to freezing meltwater ponds by rapid atmospheric cooling in autumn. König et al. [2002], Langley et al. [2007], Pälli et al. [2003] and Brandt et al. [2008] showed that multiyear superimposed ice mainly affects the elevation belts close to the equilibrium line altitude of the glacier and thus has a major impact on the thermal regime (release of latent heat) and the mass balance (meltwater retention) there. Referring to a nearby glacier (Midre Lovénbreen), Wadham et al. [2006] noted that extreme warm air advection and associated melt events can induce formation of superimposed ice even during winter. On Kongsvegen this occurred, e.g., in 2006 and 2007. 


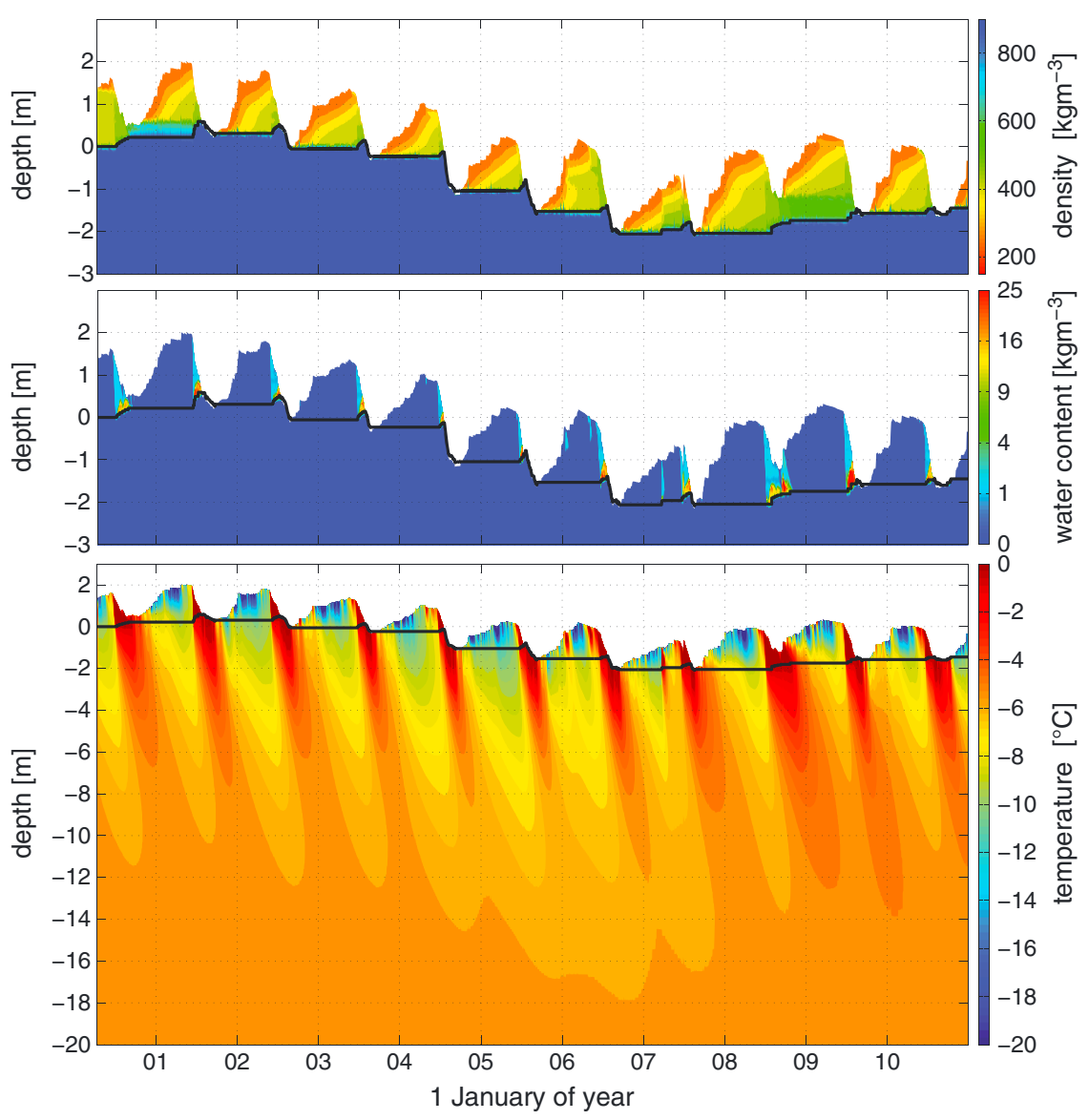

Figure 7. (top) Time-depth evolution of snow density, (middle) snow liquid water content, and (bottom) ice temperature during the decade 2001-2010 The black line delineates the snow-ice transition, rising sections indicate formation of superimposed ice.

[46] The model results also allow us to investigate the thermal regime of the near-surface snow and ice layers. Figure 7 (bottom panel) shows the typical effects of heat conduction in response to atmospheric temperature changes. Winter cold waves are strongly damped by the presence of snow. Thus, the snow-ice interface hardly cools beyond $-10^{\circ} \mathrm{C}$ while the minimum air temperatures can be as low as $-37^{\circ} \mathrm{C}$. From 2001 until 2006 the winter cold waves progressively penetrated deeper into the ice, while a warming of the deeper ice layers is apparent afterwards. This development was due to a specific combination of air temperatures and accumulated snow. Average air temperatures from 2001 to 2006 were significantly below average than for the years afterward $\left(-9.9^{\circ} \mathrm{C}\right.$ vs. $\left.-8.8^{\circ} \mathrm{C}\right)$ while the average amount of snow was relatively small during the first half compared to the second half of the decade $(1.5 \mathrm{~m}$ vs. $1.9 \mathrm{~m}$ ). Note also that there was enhanced formation of superimposed ice after 2006 (Figure 7, red areas in middle panel), which also contributed to a warming of deeper layers. Seasonal variability of near-surface ice temperature is confined to the upper $\sim 15 \mathrm{~m}$, where temperature varies by less than $0.2^{\circ} \mathrm{C}$ (Figure 7, bottom panel). At this depth, the mean ice temperature is significantly higher compared to the mean air temperature $\left(-4.7^{\circ} \mathrm{C}\right.$ vs. $\left.-9.3^{\circ} \mathrm{C}\right)$.

[47] The cumulative specific surface mass balance throughout the investigated decade was $-1.82 \mathrm{~m} \mathrm{w}$. eq. yielding the observed lowering of the ice surface. Table 2 and Figure 6 (bottom panel) show that the gain in mass was mainly due to snow accumulation (94\%), with minor contributions from refreezing rain (3\%) and condensation (2\%). Notably, rain also contributes during winter, when even some runoff can occur. The latter is associated to major intrusions of warm air masses. Conversely, there is also some snow accumulation during summer (JJA). Figure 6 further reveals considerable interannual variability of the local surface mass balance at site EBS, ranging from $-0.78 \mathrm{~m} \mathrm{w}$. eq. (2004) to $+0.65 \mathrm{~m} \mathrm{w}$. eq. (2008). The former year was characterized by very low snow accumulation $(1.4 \mathrm{~m})$, negligible formation of superimposed ice and high energy input during summer. Conversely, the strongly positive mass balance during year 2008 was the result of a record high amount of winter snow $(2.2 \mathrm{~m})$, two major snow fall events during the ablation season, and an early start of accumulation in autumn yielding the lowest energy balance recorded during the decade. This year also experienced a significant formation of superimposed ice which mostly survived the summer. It is finally noted that the specific surface mass balance at site EBS is significantly correlated to the surface mass balance of the total glacier $\left(r^{2}=0.69\right)$, as expected for a site close to the equilibrium line altitude.

\subsection{Sensitivity Studies}

[48] An additional set of model runs was performed after systematically perturbing model input parameters. Such sensitivity studies are invaluable for judging the potential influence of uncertainties related to model input and 
parameterizations. Moreover, the gross response of glacier mass balance to assumed environmental changes can be addressed as well.

\subsubsection{Effects Due to Uncertainties of the Input Data}

[49] The effective accuracy of unattended meteorological measurements in harsh Arctic environments can hardly be quantified. To estimate the effect of such uncertainties on our energy and mass balance calculations, we perturb key meteorological inputs using measurement uncertainties specified by the manufacturers of the sensors (Table 1). Note that these perturbations were applied throughout the whole simulation period. However, such systematic biases are rather unlikely and therefore the following sensitivity studies encompass extreme uncertainties of the calculated energy and mass balance.

[50] Air temperature is assumed to be measured with an effective accuracy of about $\pm 0.3^{\circ} \mathrm{C}$. A corresponding positive bias of the input data yields enhanced turbulent fluxes, which is partly offset by a stronger radiative loss (Table 3 ). Still, this leaves more energy at the surface, leading to more melt compared with the reference run. An assumed $2 \%$ increase in relative humidity also yields more energy at the surface and cumulative melt is enhanced by $\sim 10 \%$, mostly due to the influence of enhanced condensation. Perturbing wind speeds within the assumed uncertainty $\left(+0.3 \mathrm{~m} \mathrm{~s}^{-1}\right)$ primarily reinforces the turbulent heat exchanges, which is partly offset by stronger radiative losses due to the coupling by surface temperature. The resultant increase in available energy at the surface enhances the calculated mass loss; about $0.3 \mathrm{~m}$ of ice would be lost additionally, compared to the reference run. A $10 \%$ perturbation of input shortwave radiation has a strong and direct effect on net radiation. Turbulent fluxes are moderately reduced, but the calculated surface energy balance increases and leads to a mass loss almost twice as large as calculated in the reference run. The largest impact on the calculated mass balance is caused by perturbing the incoming longwave radiation data by about $10 \%$. The average surface temperature would rise by almost $1^{\circ} \mathrm{C}$, inducing negligible sensible heat flux and evaporation instead of the otherwise prevailing condensation. Naturally, a $10 \%$ increase in precipitation has only a small effect on the energy balance but it results in a less negative mass budget. Roughness lengths were not measured directly and are remain uncertain. Associated sensitivity studies show that results are most sensitive regarding the $z_{0}$ for snow, but even changes by an order of magnitude have comparatively small impacts on the energy- and mass-balance calculations. Forcing the model to immediately drain water upon reaching impermeable layers diminishes meltwater retention and prohibits the formation of superimposed ice. This results in a more negative surface mass balance compared to the reference run. In other words, these calculations indicate that in terms of cumulative mass balance the refreezing processes saved about $300 \mathrm{~mm}$ w. eq. throughout the decade.

[51] We also address the impact of uncertainties in the input vertical temperature profile applied at the start of the simulations. Data for the reference run were based on earlier measurements [Björnsson et al., 1996], but conditions may have changed in the meantime. However, the impact of a perturbation by $1^{\circ} \mathrm{C}$ on the simulated energy and mass budget is rather small (Table 3 ).

[52] The potential impact of combined, i.e., accumulated uncertainties is demonstrated by two exemplary studies. Referring to air temperature firstly, the worst case combination of the documented uncertainties due to instrument specifications, corrections and the need to fill gaps (Temperature $+1.3^{\circ} \mathrm{C}$ in Table 3 ) has moderate effects on the calculated energy and mass balance (12.7/-5.1. vs. $9.5 \mathrm{~W} \mathrm{~m}^{-2} /-1.8 \mathrm{~m}$ w. eq. in the reference run). Similar holds true regarding the straightforward accumulation of multiparameter uncertainties as demonstrated regarding the data filling procedure $(6.4 / 0.7$ vs. $9.5 \mathrm{~W} \mathrm{~m}^{-2} /-1.8 \mathrm{~m} \mathrm{w}$. eq. in the reference run; see line before in Table 3). Of course these are just exemplary combinations out of the many possible. Note however, that we have addressed some likely extreme cases, i.e., worst case scenarios because we did not consider that effective errors can be smaller due to partly cancelling of individual effects. We think that our data provide a most useful base to investigate the topic in a more systematically manner than possible now.

[53] Based on the current evidence, the sign and magnitude of the calculated fluxes proved mostly robust with respect to the documented estimates of uncertainties of model input data and key parameters. The uncertainty of the energy balance results may be quantified by the standard deviation of the perturbed runs (Table 3) yielding a value of $\pm 2.1 \mathrm{~W} \mathrm{~m}^{-2}$. Comparing the figures for the individual components with those in Figure 3 (vertical bars) shows that the seasonal as well as the interannual variations are about one order of magnitude larger and thus well outside the range of uncertainty as far as

Table 3. Mean Energy Balance Components $\left(\mathrm{W} \mathrm{m}^{-2}\right)$ for Different Model Settings and the Resulting Changes in the Energy and Mass Balance (m w. eq.) During the Decade 2001-2010. Abbreviations Follow Equation (1) and (3), Respectively

\begin{tabular}{|c|c|c|c|c|c|}
\hline & NR & SHF & LHF & SEB & MB \\
\hline Reference run & -1.1 & 9.2 & 1.4 & 9.5 & -1.8 \\
\hline Temperature $+0.3^{\circ} \mathrm{C}$ & -1.7 & 10.0 & 1.9 & 10.2 & -2.5 \\
\hline Rel. humidity $+2 \%$ & -1.3 & 8.8 & 2.3 & 9.8 & -2.0 \\
\hline Wind speed $+0.3 \mathrm{~m} \mathrm{~s}^{-1}$ & -1.6 & 9.9 & 1.5 & 9.8 & -2.0 \\
\hline Solar insolation $+9 \mathrm{~W} \mathrm{~m}^{-2}$ & 1.8 & 8.2 & 0.9 & 10.9 & -3.1 \\
\hline Longwave incoming radiation $+23 \mathrm{Wm}^{-2}$ & 17.7 & 0.0 & -2.3 & 15.4 & -7.5 \\
\hline Precipitation $+10 \%$ & -1.4 & 9.2 & 1.5 & 9.3 & -0.9 \\
\hline$z_{0}$ frozen snow $=0.0002 \mathrm{~m}$ & -0.3 & 8.4 & 1.4 & 9.5 & -1.8 \\
\hline $\mathrm{z}_{0}$ melting snow $=0.0004 \mathrm{~m}$ & -1.1 & 8.9 & 1.3 & 9.1 & -1.5 \\
\hline$z_{0}$ ice $=0.0008 \mathrm{~m}$ & -1.1 & 9.1 & 1.4 & 9.3 & -1.6 \\
\hline All water on top of ice runs off & -1.3 & 9.5 & 1.7 & 9.9 & -2.1 \\
\hline Initial temperature profile $+1^{\circ} \mathrm{C}$ & -1.2 & 9.2 & 1.4 & 9.4 & -1.8 \\
\hline Accumulated uncertainty for air temperature $\left(+1.3^{\circ} \mathrm{C}\right)$ & -3.3 & 12.7 & 3.3 & 12.7 & -5.1 \\
\hline Multiparameter uncertainty: $\left(T+0.3^{\circ} \mathrm{C} ; \mathrm{rh}, 8 \%\right.$; ws, $0.8 \mathrm{~m} \mathrm{~s}^{-1} ; \mathrm{SI}, 2.1 \mathrm{~W} \mathrm{~m} \mathrm{~m}^{-2}$ LIR, $\left.5.9 \mathrm{~W} \mathrm{~m} \mathrm{~m}^{-2}\right)$ & -4.1 & 11.2 & -0.7 & 6.4 & 0.7 \\
\hline Standard deviation of perturbed runs & 5.5 & 2.9 & 1.4 & 2.1 & 2.0 \\
\hline
\end{tabular}


judged by the above mentioned measures. The calculations respond most pronounced to imposed perturbations of the input radiation components, emphasizing the need to improve the accuracy of right these data in future. Future studies may also employ randomly applied error scenarios compared to assuming constant biases throughout the whole period. An interesting approach in that direction was recently put forward by Mölg et al. [2012].

\subsubsection{Basic Climate Impacts}

[54] Sensitivity studies may also indicate the response of the energy and mass balance to potential climate changes. We do not consider transient climate scenarios as proposed by, e.g., Christensen et al., [2007]; we follow instead Oerlemans and Reichert [2000] and calculate the response of the annual mass balance to prescribed monthly changes in temperature and precipitation. Thus, a monthly perturbation of air temperature by $+1^{\circ} \mathrm{C}$ substantially affects summer melt and causes more negative mass balances compared to the reference run (Figure 8, left). The slight increases in mass balance during winter reflect the net mass gain due enhanced condensation. For all months, a 10\% increase in precipitation leads to a more positive mass balance. This basic analysis conforms to the findings by Oerlemans et al., [2005], using another model and other data. The pattern appears characteristic for Arctic ice caps and glaciers and is clearly different from the pattern for Greenland or the subpolar glaciers.

[55] Application of prescribed monthly perturbations but with a negative sign demonstrates that the resulting pattern of the monthly sensitivity characteristics is almost but not strictly mirrored (Figure 8, right panel). Negative temperature and precipitation changes tend to be more pronounced than the effects due to positive perturbations. These differences are most pronounced during late summer, for temperature, which indicates feedback processes inducing a hysteresis in the response of glacier mass balance to climate forcings. Refreezing processes can play an important role in this context, and should be investigated in more detail.

\section{Conclusions and Perspectives}

[56] We use meteorological observations made close to the average equilibrium line of the glacier Kongsvegen to drive a numerical energy and mass balance model. We analyze average daily and seasonal cycles, as well as the interannual variations of the meteorological parameters and of the mass and energy balance components, over the course of a full decade. Analysis of the results also considers the validation of crucial model parameters by independent observations, while uncertainties of the results are addressed by sensitivity studies.

[57] Local meteorological conditions during the decade 2001-2010 were characterized by an average air temperature of $-9.3^{\circ} \mathrm{C}$, relatively high humidity $(90 \%)$ and moderate wind speeds $\left(4.6 \mathrm{~m} \mathrm{~s}^{-1}\right)$. Air temperatures can be positive at any time of the year, and variability was higher during winter. The summer regime settled close to $0^{\circ} \mathrm{C}$ due to the damping influence of the melting glacier. The average diurnal range of air temperature was small $\left(<2^{\circ} \mathrm{C}\right)$ and slightly enhanced during winter. There was no pronounced trend in air temperature but a sequence of colder years occurred in the earlier period. The years 2003 and 2006 stand out as the coldest and warmest years of the decade. Wind speeds were higher and more variable during winter, reflecting enhanced synoptic influence. Highest wind speeds occurred in 2006, with generally lower wind speeds afterwards. The observed wind directions were primarily down-slope and largely reflected the influence of topographically modified synoptic winds and katabatic forcing. Near-surface air layers were stably stratified on average, except for the spring months.

[58] Mean net radiation was almost balanced $\left(-1 \mathrm{~W} \mathrm{~m}^{-2}\right)$ due to several limiting and compensating factors: the polar night, which occurs from October to February; high winter albedo (0.82), and a continuously negative longwave radiation budget, due to the low atmospheric temperatures and effective emission at the surface. Net radiation was positive from May to August, with maximum values in July due to the low albedo of previous years' ice appearing at the surface at that time of the year. Annual values of net radiation ranged between $-9 \mathrm{~W} \mathrm{~m}^{-2}$ and $8 \mathrm{~W} \mathrm{~m}^{-2}$.

[59] Sensible heat flux was the most important and continuous source of energy at the surface $\left(+9 \mathrm{~W} \mathrm{~m}^{-2}\right)$. This was due to the quasi-persistent inversion conditions. It can be negative during spring months, which is related to subzero surface temperatures at a time when solar insolation is already strong. Latent heat flux was a source of energy except during summer or particularly dry years (2006). Year-to-year variability shows enhanced turbulent heat fluxes in the second half of the decade. The cold content of the top $25 \mathrm{~m}$ of snow and ice featured a regular change in sign throughout the seasons and
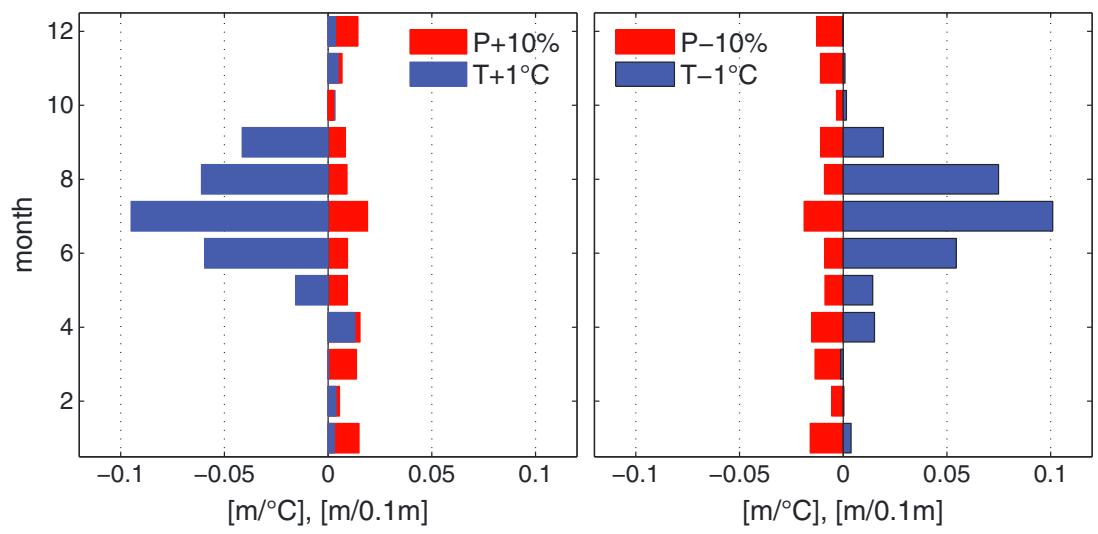

Figure 8. Monthly sensitivity studies: Impact on the mean annual specific mass balance calculated at EBS for monthly precipitation and temperature perturbations. 
was slightly diminishing throughout the investigated decade. The influence of rain was negligible in general. Overall there was a surplus of energy at the glacier surface $\left(+9.5 \mathrm{~W} \mathrm{~m}^{-2}\right)$. Only a small part of this available energy was used to heat the ice; $98 \%$ of the available energy went into melt.

[60] At the elevation of the EBS the glacier experienced a negative surface mass balance throughout the investigated decade ( $-1.8 \mathrm{~m}$ w. eq.). The most significant mass loss occurred during the period 2004-2007, as corroborated by independent observations of the total mass balance of the glacier, while mass balance was mostly positive toward the end of the decade.

[61] Accumulation takes place during October until April, and the major amounts usually stem from a few events in autumn and early spring. Refreezing rain contributed only about $4 \%$ to the total mass gain, with similarly small amounts provided by condensation. Mass loss was mainly due to runoff, of which a small part $(6 \%)$ also occurred during warm winter periods. A negligible amount of mass was also lost through evaporation.

[62] The average length of the ablation period was 80 days. In early spring of each year, superimposed ice was formed reaching a thickness of about $20 \mathrm{~cm}$. Normally, this ice melted during the later melt period. Particularly large amounts of superimposed ice developed in 2001, 2005, 2008, and 2009, which partly survived the remaining melt period. The associated mass retention and release of latent heat are important factors for the mass balance and the thermal regime of the glacier.

[63] Sensitivity studies showed that the energy balance is most sensitive to uncertainties in the radiation components (longwave radiation in particular), while uncertainties in model parameterizations (initial temperature profile, roughness lengths, and meltwater retention) appear less critical. These sensitivity experiments also provided a measure of the total uncertainty of the calculated energy balance, which is quantified as $+9.5 \pm 2.1 \mathrm{~W} \mathrm{~m}^{-2}$. The seasonal and interannual variations of the calculated energy budget components proved robust compared to accumulated uncertainties introduced by instrument corrections and the need to partly fill gaps in the records. Further sensitivity studies showed that the glacier mass balance is most sensitive to perturbations in summer air temperature, while perturbations in precipitation affect all seasons equally.

[64] Acknowledgments. This research was supported by the Austrian Science Fund (FWF, grant I 369-B17), by EU (contract ENV4-CT97-0490), and by the Svalbard Science Forum (ARCFAC V 2007, EC contract 026129-75). Field work was performed in cooperation with the Norwegian Polar Institute (Tromsoe) and University of Oslo. We further acknowledge the help by staff and students from the Institute of Meteorology and Geophysics, Innsbruck University. AWI (Bremerhaven, Marion Maturilli) is thanked for providing Ny-Ålesund meteorological data. Work on the topic of this investigation was performed by S. Erath in context of his Diploma thesis developed at the Institute of Meteorology and Geophysics, Innsbruck University, which is gratefully acknowledged, too.

\section{References}

Anderson, E. A. (1976), A point energy and mass balance model of a snow cover, U.S. Dept. of Commerce, National Oceanic and Atmospheric Administration, National Weather Service, Office of Hydrology, Silver Spring, Md.

Andreas, E. L. (1987), A theory for the scalar roughness and the scalar transfer coefficients over snow and sea ice, Boundary Layer Meteorology, $38(1-2), 159-184$.

Arendt, A. (1999), Approaches to Modelling the Surface Albedo of a High Arctic Glacier, Geografiska Annaler: Series A, Physical Geography, 81(4), 477-487.

Argentini, S., A. P. Viola, G. Mastrantonio, A. Maurizi, T. Georgiadis, and M. Nardino (2003), Characteristics of the boundary layer at Ny-Ålesund in the arctic during the artist fi eld experiment, Annals of Geophysics, 46(2), 185-196.

Arnold, N.S., W.G. Rees, A.J. Hodson, and J. Kohler (2006), Topographic controls on the surface energy balance of a high Arctic valley glacier, Journal of Geophysical Research, 111(F2), F02011, doi:10.1029/2005JF000426.

Bamber, J., W. Krabill, V. Raper, and J. Dowdeswell (2004), Anomalous recent growth of part of a large arctic ice cap: Austfonna, Svalbard, Geophysical Research Letters, 31, L12402, doi:10.1029/2004GL019667.

Björnsson, H., Y. Gjessing, S. E. Hamran, J. O. Hagen, O. Listøl, F. Palsson, and B. Erlingsson (1996), The thermal regime of sub-polar glaciers mapped by multi-frequency radio-echo sounding, Journal of Glaciology, 42(140), 23-32.

Bougamont, M., J. L. Bamber, and W. Greuell (2005), A surface mass balance model for the Greenland Ice Sheet, Journal of Geophysical Research, 110, F04018, doi:10.1029/2005JF000348.

Brandt, O., J. Kohler, and M. Lüthje (2008), Spatial mapping of multi-year superimposed ice on the glacier Kongsvegen, Svalbard, Journal of Glaciology, 54(184), 73-80, doi:10.3189/002214308784409080

Christensen, J., et al. (2007) Regional Climate Projections, in: Climate Change 2007: The Physical Science Basis. Contribution of Working Group I to the Fourth Assessment Report of the Intergovernmental Panel on Climate Change, edited by Solomon, S., D. Qin, M. Manning, Z. Chen, M. Marquis, K.B. Averyt, M. Tignor and H.L. Miller, pp. 847-940, Cambridge University Press, Cambridge, United Kingdom and New York, USA.

Coléou, C., and B. Lesaffre (1998), Irreducible water saturation in snow: experimental results in a cold laboratory, Annals of Glaciology, 26, 64-68.

Cullen, N. J., and K. Steffen (2001), Unstable Near-Surface Boundary Conditions in Summer on Top of the Greenland Ice Sheet, Geophysical Research Letters, 28, 4491-4493, doi:10.1029/2001GL013417.

Denby, B., and C. J. J. Smeets (2000), Derivation of turbulent flux profiles and roughness lengths from katabatic flow dynamics, Journal of applied Meteorology, 39, 1601-1612, doi: 10.1175/1520-0450(2000) $039<1601:$ DOTFPA $>2.0 . \mathrm{CO} ; 2$

Erath, S. (2005), Simulation of the mass and energy balance at Kongsvegen 2001-2003. M.S. thesis, 83 pp., Department of Meteorology and Geophysics, University Innsbruck, Innsbruck, Austria.

Esau, I., and I. Repina (2012), Wind Climate in Kongsfjorden, Svalbard, and Attribution of Leading Wind Driving Mechanisms through Turbulence-Resolving Simulations, Advances in Meteorology, 2012, Article ID 568454, 16, doi:10.1155/2012/568454.

Førland, E. J., R. Benestad, I. Hanssen-Bauer, J. E. Haugen, and T. E. Skaugen (2011), Temperature and Precipitation Development at Svalbard 1900-2100, Advances in Meteorology, 2011, 1-14, doi:10.1155/2011/893790.

Greuell, W., and C. Genthon (2003), Modelling land-ice surface balance, in Mass Balance of the Cryosphere: Observations and Modelling of Contemporary and Future Changes, edited by Bamber J. and Payner, J. Cambridge University Press, Cambridge, UK and New York, NY, USA. Greuell, W., J. Kohler, F. Obleitner, P. Glowacki, K. Melvold, E. Bernsen, and J. Oerlemans (2007), Assessment of interannual variations in the surface mass balance of 18 Svalbard glaciers from the Moderate Resolution Imaging Spectroradiometer/Terra albedo product, Journal of Geophysical Research, 112, D07105, doi:10.1029/2006JD007245.

Greuell, W., and T. Konzelmann (1994), Numerical modelling of the energy balance and the englacial temperature of the Greenland Ice Sheet. Calculations for the ETH-Camp location (West Greenland, $1155 \mathrm{~m}$ a.s.1.), Global and Planetary Change, 9(1-2), 91-114, doi:10.1016/0921-8181(94)90010-8.

Greuell, W., and J. Oerlemans (1987), Sensitivity studies with a mass balance model including temperature profile calculations inside the glacier, Zeitschrift fuer Gletscherkunde und Glazialgeologie, 22, 101-124.

Hagen, J. O., J. Kohler, K. Meldvold, and J. G. Winther (2003a), Glaciers in Svalbard: mass balance, runoff and freshwater flux, Polar Research, 22, 145-159, doi:10.1111/j.1751-8369.2003.tb00104.x.

Hagen, J. O., and O. Listøl (1990), Long term glacier mass balance investigations in Svalbard 1950-1988. Annals of Glaciology, 14, 102-106.

Hagen, J. O., K. Melvold, F. Pinglot, and J. A. Dowdeswell (2003b), On the Net Mass Balance of the Glaciers and Ice Caps in Svalbard, Norwegian Arctic, Arctic, Antarctic, and Alpine Research, 35(2), 264-270.

Hanssen-Bauer, I., and E. J. Førland (1998), Long-term trends in precipitation and temperature in the Norwegian Arctic: can they be explained by changes in atmospheric circulation patterns?, Climate Research, 10(2), 143-153.

Hawley, L. R., O. Brandt, E. M. Morris, J. Kohler, A.P. Sheperd, and D. J. Wingham (2008), Techniques for measuring high-resolution firn density profiles: case study from Kongsvegen, Svalbard, Journal of Glaciology, 54(186), 463-468.

Högström, U. (1988), Non-dimensional wind and temperature profiles in the atmospheric surface layer: A reevaluation, Boundary Layer Meteorology, 42, 55-78, doi:10.1007/BF00119875

Hodgkins, R. (1997), Glacier hydrology in Svalbard, Norwegian high arctic, Quaternary Science Reviews, 16, 957-973, doi:10.1016/S0277-3791(97) 00032-2. 
Johannessen, O., L. Bengtsson, M. Miles, S. Kuzmina, V. Semenov, G. Alekseev, A. Nagurnyi, V. Zakharov, L. Bobylev, L. Pettersson, K. Hasselmann, and H. Cattle (2004), Arctic climate change: observed and modelled temperature and sea ice variability, Tellus, 56A, 328-341, doi:10.1111/j.16000870.2004.00060.x.

Jordan, R. (1991), A One-Dimensional Temperature Model for a Snow Cover: Technical Documentation for SNTHERM.89, Special Report $91-16$, U.S. Army Cold Regions Research and Engineering Laboratory, New Hampshire, USA.

Kaser, G., A. Fountain, and P. Jansson (2003), A manual for monitoring the mass balance of mountain glaciers with particular attention to low latitude characteristics. A contribution from the International Commission on Snow and Ice (ICSI) to the UNESCO HKH-Friend programme, IHP-VI, Technical Documents in Hydrology, No. 59, UNESCO, Paris, France.

Klok, E. J., M. Nolan, and M. R. van den Broeke (2005), Analysis of meteorological data and the surface energy balance of McCall Glacier, Alaska, USA, Journal of Glaciology, 51(174), 451-461, doi:10.3189/ 172756505781829241

König, M., J. Wadham, J. G. Winther, J. Kohler, and A. M. Nuttall (2002), Detection of superimposed ice on the glaciers Kongsvegen and midre Lovénbreen, Svalbard, using SAR satellite imagery, Annals of Glaciology, 34(1), 335-342.

König-Langlo, G., and E. Augstein (1994), Parameterization of the downward long-wave radiation at the Earth's surface in polar regions, Meteorologische Zeitschrift, N.F.3, (H. 6),343-347.

Krismer, T. (2009), Local and Spatial Mass Balance Modelling on an Arctic Glacier Kongsvegen, Spitzbergen, M.S. thesis, 137 pp., Department of Meteorology and Geophysics, University of Innsbruck, Innsbruck, Austria

Kuipers Munneke, P., M. R. van den Broeke, C. H. Reijmer, M. M. Helsen, W. Boot, and K. Schneebeli, M. Steffen (2009), The role of radiation penetration in the energy budget of the snowpack at Summit, Greenland, The Cryosphere, 3, 155-165, doi:10.5194/tc-6-353-2012.

Kuipers Munneke, P., M. R. van den Broeke, J. C. King, T. Gray, and C. H. Reijmer, (2012), Near-surface climate and surface energy budget of Larsen C ice shelf, Antarctic Peninsula, The Cryosphere, 6, 353-363, doi:10.5194/tc-6-353-2012.

Kupfer, H., A. Herber, and G. König-Langlo (2006), Radiation measurements and synoptic observations at Ny-Ålesund, Svalbard, Reports on Polar and Marine Research, Alfred Wegener Institute for Polar and Marine Research, Bremerhaven, ISSN: 1618-3193

Langley, K., S. E. Hamran, K. Hogda, R. Storvold, O. Brandt, J. Hagen, and J. Kohler (2007), Use of CBand Ground Penetrating Radar to Determine Backscatter Sources Within Glaciers, Geoscience and Remote Sensing, IEEE Transactions on, 45(5), 1236-1246, doi:10.1109/ TGRS.2007.892600

Lefauconnier, B., J. O. Hagen, J. B. Örbaek, K. Melvold, and E. Isaksson (1999), Glacier balance trends in the Kongsfjorden area, western Spitsbergen, Svalbard, in relation to the climate, Polar Research, 18, 307-313, doi:10.1111/j.1751-8369.1999.tb00308.x.

Lemke, P., J. Ren, R. B. Alley, I. Allison, J. Carrasco, G. Flato, Y. Fujii, G. Kaser, P. Mote, R. Thomas, and T. Zhang, (2007), Observations: Changes in Snow, Ice and Frozen Ground, in Climate Change 2007: The Physical Science Basis. Contribution of Working Group I to the Fourth Assessment Report of the Intergovernmental Panel on Climate Change, edited by Solomon, S., D. Qin, M. Manning, Z. Chen, M. Marquis, K. B. Averyt, M. Tignor and H. L. Miller, pp. 356-360, Cambridge University Press, Cambridge, United Kingdom and New York, USA.

Melvold, K., and J.O. Hagen (1998), Evolution of a surge-type glacier in its quiescent phase: Kongsvegen, Spitsbergen, 1964-95, Journal of Glaciology, 44(147), 394-404.

Mäkiranta, E., T. Vihma, A. Sjöblom, and E.M. Tastula (2011), Observations and Modelling of the Atmospheric Boundary Layer Over Sea-Ice in a Svalbard Fjord, Boundary Layer Meteorology, 140(1), 105-123, doi:10.1007/s10546011-9609-1.

Moholdt, G., C. Nuth, J. O. Hagen, and J. Kohler (2010), Recent elevation changes of svalbard glaciers derived from icesat laser altimetry, Remote Sensing of Environment, 114(10), 2756-2767, doi:10.1109/TGRS.2008.2000627.

Mölg, T., F. Maussion, W. Yang, and D. Scherer (2012), The footprint of Asian monsoon dynamics in the mass and energy balance of a Tibetan glacier, The Cryosphere Discuss., 6, 3243-3286, doi:10.5194/tcd-6-3243-2012.

Nicolaus, M., C. Haas, and J. Bareiss (2003), Observations of superimposed ice formation at melt-onset on fast ice on Kongsfjorden, Svalbard, Physics and Chemistry of the Earth, 28, 1241-1248, doi:10.1016/j.pce.2003.08.048

Nuth, C., G. Moholdt, J. Kohler, J.O. Hagen, and A. Kääb (2010), Svalbard glacier elevation changes and contribution to sea level rise, Journal of Geophysical Research, 115, F01008, doi:10.1029/2008JF001223.

Obleitner, F. (2000), The energy budget of snow and ice at Breidamerkurjökull, Vatnajökull, Iceland, Boundary-Layer Meteorology, 97, 385-410, doi:10.1023/A:1002734303353.
Obleitner, F., N. Cullen, and K. Steffen (2007), Simulation of the turbulent fluxes at Summit, Greenland, in: The Dynamics and Mass Budget of Arctic Glaciers, Extended abstracts Workshop and GLACIODYN (IPY) Meeting, 15 - 18 January 2007, Pontresina (Switzerland), IASC Working Group on Arctic Glaciology, pp. 76-80.

Obleitner, F., and J. De Wolde (1999), On intercomparison of instruments used within the Vatnajökull glaciometeorological experiment, Boundary-Layer Meteorology, 92(1), 25-35, doi:10.1023/A:1002074627334.

Obleitner, F., and M. Lehning (2004), Measurement and simulation of snow and superimposed ice at the Kongsvegen glacier, Svalbard (Spitzbergen), Journal of the Geophysical Research, 109, D04106, doi: 10.1029/2003JD003945.

Oerlemans, J., R. Bassfort, W. Chapman, J. Dowdeswell, A. Glazovsky, J. O. Hagen, K. Meldvold, M. De Ruyter, and R. Van de Wildt (2005), Estimating the contribution of Arctic glaciers to sea-level change in the next 100 years, Annals of Glaciology, 42(1), 230-236.

Oerlemans, J., and B. Reichert (2000), Relating glacier mass balance to meteorological data by using a seasonal sensitivity characteristic, Journal of Glaciology, 46(152), 1-6, doi:10.3189/172756500781833269.

Overland, J. E., M.C. Spillane, D. B. Percival, M. Wang, and H. O. Mofjeld (2004), Seasonal and Regional Variation of Pan-Arctic Surface Air Temperature over the Instrumental Record, Journal of Climate, 17, 3263-3282, doi:10.1175/1520-0442(2004)017<3263:SARVOP>2.0.CO;2.

Papadopoulos, K. (2010), The summer climate of kongsvegen glacier. M.S thesis, 64 pp., Institute for Marine and Atmospheric Research Utrecht, Utrecht University, Utrecht, The Netherlands.

Pälli, A., J. C. Moore, J. Jania, K. Leszek, and P. Glowacki (2003), The drainage pattern of Hansbreen and Werenskioldbreen, two polythermal glaciers in Svalbard, Polar Research, 22(2), 355-371, doi:10.1111/ j.1751-8369.2003.tb00117.x.

Reijmer, C. H., and R. Hock (2008), Internal accumulation on Storglaciären, Sweden, in a multi-layer snow model coupled to a distributed energy- and mass-balance model, Journal of Glaciology, 54(184), 61-72, doi:10.3189/ 002214308784409161.

Sandvik, A. D., and B. R. Furevik (2002), Case Study of a Coastal Jet at Spitsbergen - Comparison of SAR- and Model-Estimated Wind, Monthly Weather Review, 130(4), 1040-1051, doi:10.1175/1520-0493(2002) $130<1040$ :CSOACJ $>2.0 . \mathrm{CO} ; 2$.

Smeets, C. J. J. (2006), The mass budget of arctic glaciers, in: Extended abstracts Workshop and GLACIODYN planning meeting, 29 January 3 February 2006 Obergurgl (Austria),pp. 99-101.

Stütz, E. (2010), Dynamically and thermally driven flows over and around Svalbard: A case study based on numerical simulations and airborne measurements. M.S. thesis, 127 pp., University of Innsbruck, Innsbruck, Austria.

Van den Broeke, M. R., D. van As, C. H. Reijmer and R. S. W. van de Wal (2004), Assessing and improving the quality of unattended radiation observations in Antarctica, Journal of Atmospheric and Oceanic Technology, 21(9), 1417-1431, doi:10.1175/1520-0426(2004)021<1417:AAITQO > 2.0. $\mathrm{CO} ; 2$

Van den Broeke, M. R., C. H. Reijmer, D. van As, R. S. W. van de Wal, and J. Oerlemans (2005), Seasonal cycles of Antarctic surface energy balance from Automatic Weather Stations, Annals of Glaciology, 41(1), 131-139, doi: $10.3189 / 172756405781813168$.

Van den Broeke, M. R., R. C., D. van As, and W. Boot (2006), Daily cycle of the surface energy balance in Antarctica and the influence of clouds, International Journal of Climatology, 26, 1587-1605. doi:10.1002/joc.1323.

Wadham, J., J. Kohler, A. Hubbard, A. M. Nuttall, and D. Rippin (2006), Superimposed ice regime of a high Arctic glacier inferred using groundpenetrating radar, flow modeling, and ice cores, Journal of Geophysical Research, 111(F1), F01007, doi:10.1029/2004JF000144.

Warren, S., and W. Wiscombe (1980), A model for the spectral albedo of snow: I: Pure snow, Journal of the Atmospheric Sciences, 37, 2712-2733, doi:10.1175/1520-0469(1980)037<2712:AMFTSA > 2.0.CO;2.

Westermann, S., J. Lüers, M. Langer, K. Piel, and J. Boike (2009), The annual surface energy budget of a high-arctic permafrost site on Svalbard, Norway. The Cryosphere, 3, 245-263, doi:10.5194/tc-3-245-2009

WGMS (2009), Glacier Mass Balance Bulletin No. 10 (2006-2007), edited by Haeberli, W., I. Gärtner-Roer, M. Hoelzle, F. Paul and M. Zemp, CSU (WDS)/IUGG(IACS)/UNEP/UNESCO/WMO, World Glacier Monitoring Service , Zürich, $96 \mathrm{pp}$.

Wright, A., J. Wadham, M. Siegert, A. Luckman, and J. Kohler (2005), Modelling the impact of superimposed ice on the mass balance of an Arctic glacier under scenarios of future climate change. Annals of Glaciology, 42(1),277-283, doi:10.3189/172756405781813104.

Zuo, Z., and J. Oerlemans (1996), Modelling albedo and specific balance of the Greenland ice sheet: calculations for the Søndre Strømfjord transect, Journal of Glaciology, 42(141), 305-317. 